\title{
Sources of nitrous acid (HONO) in the upper boundary layer and lower free troposphere of the North China Plain: insights from the Mount Tai Observatory
}

\author{
Ying Jiang ${ }^{1}$, Likun Xue ${ }^{1,4}$, Rongrong Gu ${ }^{1}$, Mengwei Jia ${ }^{2}$, Yingnan Zhang ${ }^{1}$, Liang Wen ${ }^{1}$, Penggang Zheng ${ }^{1}$, \\ Tianshu Chen ${ }^{1}$, Hongyong $\mathrm{Li}^{1}$, Ye Shan ${ }^{1}$, Yong Zhao ${ }^{3}$, Zhaoxin $\mathrm{Guo}^{3}$, Yujian Bi ${ }^{3}$, Hengde $\mathrm{Liu}^{3}$, Aijun Ding ${ }^{2,4}$, \\ Qingzhu Zhang ${ }^{1}$, and Wenxing Wang ${ }^{1}$ \\ ${ }^{1}$ Environment Research Institute, Shandong University, Qingdao, Shandong, 266237, China \\ ${ }^{2}$ School of Atmospheric Sciences, Nanjing University, Nanjing, 210023, China \\ ${ }^{3}$ Taishan National Reference Climatological Station, Tai' an, Shandong, 271000, China \\ ${ }^{4}$ Collaborative innovation Center for Climate Change, Jiangsu Province, Nanjing, 210023, China
}

Correspondence: Likun Xue (xuelikun@sdu.edu.cn)

Received: 19 April 2020 - Discussion started: 25 May 2020

Revised: 19 August 2020 - Accepted: 31 August 2020 - Published: 26 October 2020

\begin{abstract}
Nitrous acid (HONO) is a significant precursor of atmospheric "detergent" $\mathrm{OH}$ radicals and plays a vital role in tropospheric chemistry. The current knowledge about daytime HONO sources is incomplete, and its impact on the tropospheric radical chemistry has not been fully quantified. Existing observational studies of HONO were mostly conducted at the surface, with few efforts focusing on the highelevation atmosphere. In order to better understand the characteristics and sources of $\mathrm{HONO}$ in the upper boundary layer and lower free troposphere, two intensive field observations were carried out at the summit of Mt. Tai (1534 ma.s.l.), the peak of the North China Plain (NCP), in winter 2017 and spring 2018. HONO showed moderate concentration levels (average \pm standard deviation: $0.15 \pm 0.15$ and $0.13 \pm$ $0.15 \mathrm{ppbv}$ ), with maximum values of 1.14 and $3.23 \mathrm{ppbv}$ in winter and spring, respectively. Diurnal variation patterns with broad noontime maxima and lower nighttime concentrations were observed during both campaigns, which is distinct from most of the previous studies at the ground level. The Lagrangian particle dispersion model (LPDM, WRFFLEXPART v3.3) simulations indicated the combined effects of the planetary boundary layer evolution and valley breeze on the daytime HONO peak. A photostationary state (PSS) analysis suggested a strong unknown daytime HONO source with production rates of $0.45 \pm 0.25 \mathrm{ppb} \mathrm{h}^{-1}$ in winter and $0.64 \pm 0.49 \mathrm{ppb} \mathrm{h}^{-1}$ in spring. Correlation analysis sup-
\end{abstract}

ported the important role of photo-enhanced heterogeneous conversion of $\mathrm{NO}_{2}$ to $\mathrm{HONO}$ on the aerosol surface at this high-elevation site. HONO photolysis is the predominant primary source of $\mathrm{OH}$ radical and plays a major role in the radical chemistry at Mt. Tai. The model only considering a homogenous HONO source predicted much lower levels of the $\mathrm{HO}_{x}$ radicals and atmospheric oxidation capacity than the model constrained with measured HONO data. This study sheds light on the characteristics, sources, chemistry, and impacts of HONO in the upper boundary layer and lower free troposphere in the NCP region.

\section{Introduction}

Nitrous acid (HONO) is an important reactive trace gas in the Earth's atmosphere and plays a pivotal role in tropospheric oxidation chemistry. Photolysis of HONO by sunlight releases the hydroxyl radical $(\mathrm{OH})$, which initiates the oxidation reaction cycles, resulting in the degradation of various primary contaminants and formation of secondary pollutants such as ozone $\left(\mathrm{O}_{3}\right)$ and secondary aerosols (Alicke et al., 2003). HONO can react with amines to form nitrosamines, which are mutagenic and carcinogenic, and thus affects human health (Sleiman et al., 2010). HONO is also a key player in biosphere-atmosphere interactions and the biogeochemi- 
cal cycle via dry and wet depositions as well as soil microbial processes (Sörgel et al., 2015). Therefore, it is of high significance to better understand the characteristics, sources, sinks, and environmental consequences of tropospheric HONO.

In comparison to the sink processes that have been relatively well understood, the sources of ambient HONO are still under extensive exploration and discussion. In the ambient atmosphere, HONO can be either directly emitted from various processes, such as combustion and soil emissions ( $\mathrm{Su}$ et al., 2011; Nie et al., 2015), or formed from the photolysis and chemical reactions of reactive nitrogen-containing substances. The gas-phase reaction of NO with OH (Reaction R1) has long been known as a significant formation pathway of HONO (Platt et al., 1980), which forms a pseudosteady state with the fast photolysis of HONO in sunlight (Reaction R2) and the reactions with OH (Reaction R3) during the daytime. HONO concentrations in photostationary state (PSS; [HONO $]_{P S S}$ ) can be calculated by Eq. (1). However, the field observations in the last decade have indicated that the $[\mathrm{HONO}]_{\text {PSS }}$ can only account for a small portion of the measured concentrations in a variety of environments (Kleffmann et al., 2005; Zhou et al., 2007; Michoud et al., 2014), suggesting the action of additional daytime HONO sources. To explain the observed HONO levels, some new formation mechanisms have been proposed and tested in the lab or through field studies (Bejan et al., 2006; Monge et al., 2010; Su et al., 2011; Li et al., 2014). Among them, a widely well-received HONO source is the heterogeneous reactions of $\mathrm{NO}_{2}$ on various wet surfaces (Reaction $\mathrm{R} 4$ ), including the ground, buildings, urban grime, and aerosol surfaces (Villena et al., 2011; Wong et al., 2012; Liu et al., 2014; Baergen and Donaldson, 2016). However, the contributions of the individual surface types to ambient HONO formation have not been figured out. Most previous studies have suggested the dominance of the ground surface in heterogeneous HONO formation at the ground level (Alicke et al., 2003; Elshorbany et al., 2009; Ziemba et al., 2010), while some studies have argued that aerosol surface may also play an important role (Colussi et al., 2013; Liu et al., 2014; Tong et al., 2016; Lu et al., 2018).

$\mathrm{NO}+\mathrm{OH} \stackrel{M}{\longrightarrow} \mathrm{HONO}$
$\mathrm{HONO} \stackrel{h v}{\longrightarrow} \mathrm{NO}+\mathrm{OH}$
$\mathrm{HONO}+\mathrm{OH} \rightarrow \mathrm{NO}_{2}+\mathrm{H}_{2} \mathrm{O}$

$[\mathrm{HONO}]_{\mathrm{PSS}}=\frac{[\mathrm{NO}] \times[\mathrm{OH}] \times K_{\mathrm{NO}+\mathrm{OH}}}{J_{\mathrm{HONO}}+[\mathrm{OH}] \times K_{\mathrm{OH}+\mathrm{HONO}}}$

$$
\begin{aligned}
2 \mathrm{NO}_{2}(g) & +\mathrm{H}_{2} \mathrm{O}(\text { surface }) \rightarrow \mathrm{HONO}(g) \\
& +\mathrm{HNO}_{3}(\text { surface })
\end{aligned}
$$

Up to now, field observational studies of HONO have mainly been conducted at the surface level, with few efforts made at high elevations such as the upper planetary boundary layer (PBL) and lower free troposphere (FT). This has hindered a thorough understanding of the characteristics, processes, and environmental impacts of tropospheric HONO. First, it can be easily expected that the HONO concentrations should be rather low in the upper PBL and lower FT, given the short lifetime of HONO under sunlight. This has been confirmed by the limited measurement studies at mountaintops and aboard aircraft (Acker et al., 2006; Zhou et al., 2007; Ye et al., 2016, 2018). Field observations at high-elevation sites could provide direct constraints for better understanding the vertical distribution and transport processes of HONO. Second, the upper PBL and lower FT are free from the terrestrial (especially ground) surfaces and hence provide an ideal opportunity to evaluate the role of aerosol particles in the heterogeneous formation of HONO. Third, the impacts of HONO on the atmospheric oxidation capacity (AOC) in the upper PBL and lower FT have not been fully quantified. Existing modeling studies may underestimate the AOC of the high-altitude atmosphere owing to the lack of observational data constraints (Kukui et al., 2014). Consequently, in situ observations of HONO in the upper PBL and lower FT are very important to achieve a comprehensive understanding of tropospheric oxidation chemistry.

To investigate the chemical and physical processes in the upper PBL and lower FT over the North China Plain (NCP), one of the most urbanized and polluted regions in China, two intensive field campaigns were carried out at Mt. Tai, the highest mountain over the region, in winter 2017 and spring 2018. This is a part of the Integrated Measurement Campaigns of Air Pollution Complex over the coastal regions of East China (iMAPEC), which aimed to deploy multiple advanced measurement platforms to investigate the threedimensional distributions and processes governing the formation of regional air pollution over eastern China. A large suite of chemical species and physical properties were measured during the campaigns. This paper describes the measurement results of HONO and related parameters, which are the first report of HONO chemistry in the upper PBL and lower FT in the NCP region. Several models including WRF-FLEXPART, PSS calculation, and the Master Chemical Mechanism (MCM) box model were used to illustrate the origins, formation, and impacts of HONO. Overall, this study demonstrates the moderate pollution levels of HONO in the upper PBL and lower FT in the NCP, and provides some new insights into the roles of aerosol surface in HONO formation as well as the significant effects of HONO photolysis on the atmospheric oxidation capacity in the high-altitude atmosphere. 


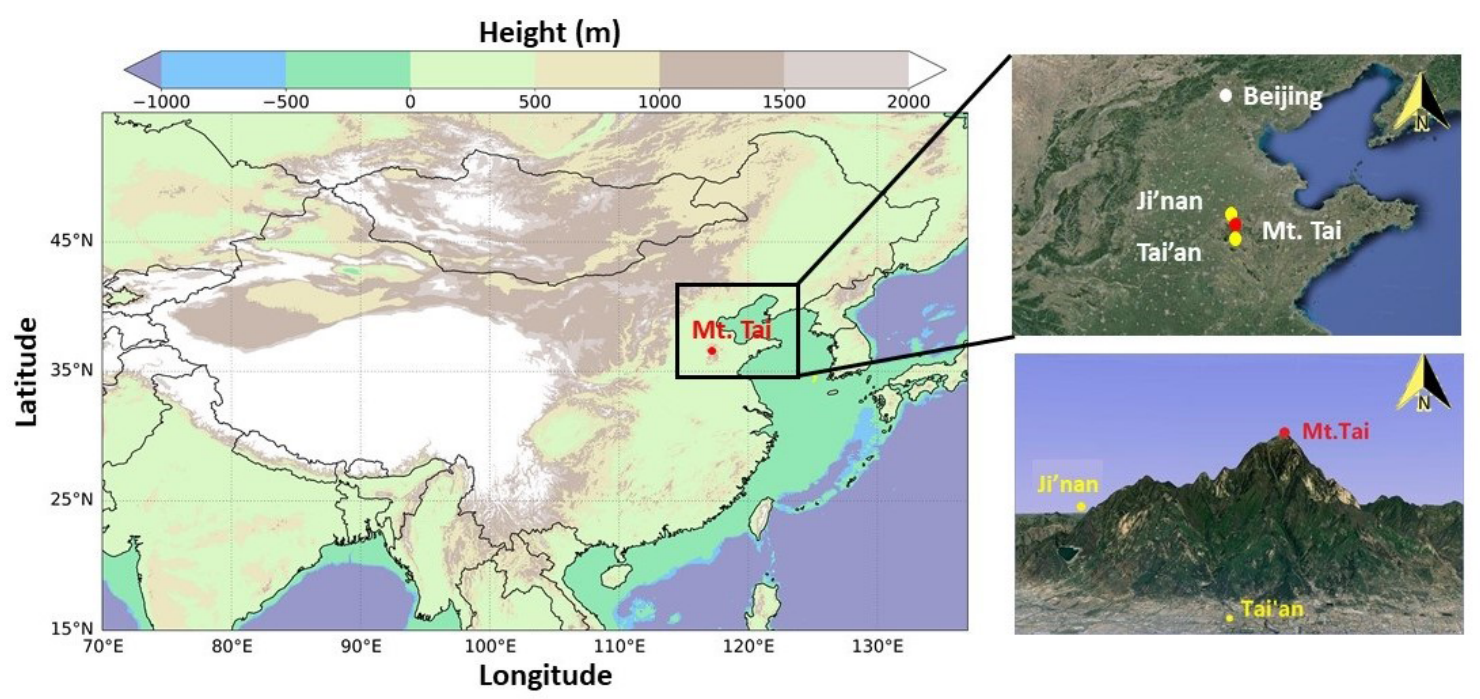

Figure 1. Maps showing the locations of Mt. Tai and the nearby cities. The left map is color-coded by the geographical height from the ETOPO1 Global Relief Model (https://www.ngdc.noaa.gov/mgg/global/, last access: 6 September 2020). The top-right map represents the North China Plain, and the bottom-right map is the 3-D shape of Mt. Tai with nearby urban regions. The maps on the right were obtained from (C) Google Earth.

\section{Methodology}

\subsection{Site description}

The Mt. Tai Observatory has been widely used as a sampling location to investigate the regional air pollution in the North China Plain region in the past decade (e.g., Gao et al., 2005; Sun et al., 2016; Wen et al., 2018). It stands at the summit of Mount Tai $\left(36^{\circ} 16^{\prime} \mathrm{N}, 117^{\circ} 6^{\prime} \mathrm{E}, 1534 \mathrm{~m}\right.$ a.s.l.), which is at the center of the NCP (see Fig. 1). The geographical location and altitude of Mount Tai make it representative of the regional background air of the region, and it is well within the upper planetary boundary layer during daytime on sunny days and in the residual layer or free troposphere at night. There are some local emissions from small restaurants and temples at the mountain, but the station is situated in the less frequently visited eastern part of the summit, and thus the impact of local anthropogenic emissions can be ignored (Gao et al., 2005). The city of Tai' an (population: over 5.5 million) is located at the foot of Mt. Tai, about $15 \mathrm{~km}$ to the south, and the capital city of Shandong province, Ji'nan (population: over 7.4 million), is situated $\sim 60 \mathrm{~km}$ to the north. It should be noted that a 1-year continuous HONO measurement campaign was conducted from September 2015 to August 2016 at an urban site in Ji'nan using the same instrument (D. Li et al., 2018), and its results are compared here with those at Mt. Tai to infer the vertical distributions of HONO in the NCP region. Details of the Mt. Tai Observatory can be found in Gao et al. (2005), Zhou et al. (2010), and Sun et al. (2016). Two intensive field measurement campaigns were conducted during 1-31 December in 2017 and from 5 March to 8 April in 2018 .

\subsection{Measurement techniques}

A large suite of chemical, physical, and meteorological parameters were measured in real time during the campaigns. Here we briefly describe the measurement techniques for the species that were used in the present study. HONO was measured by a long-path absorption photometer (LOPAP03, QUMA GmbH, Germany). It detects HONO based on the wet chemistry theory, and two channels are designed to eliminate the possible interferences. The detailed description of the LOPAP instrument has been provided by Heland et al. (2001), and it has been successfully applied in various environments (Kleffmann et al., 2005; D. Li et al., 2018; Wen et al., 2019; Y. Liu et al., 2019). During the present study, manual calibrations were performed using $1000 \mathrm{mg} \mathrm{L}^{-1} \mathrm{ni}-$ trite standard solutions every $4 \mathrm{~d}$ to examine the sensitivity of the detector, and the small drift of the baseline was corrected by regular automatic flushing with ultrapure nitrogen (purity of $99.999 \%$ ), which was done for $30 \mathrm{~min}$ at a time interval of $11 \mathrm{~h} 30 \mathrm{~min}$. The detection limit is $3 \mathrm{ppt}$ at a time resolution of $30 \mathrm{~s}$, and the measurement precision and accuracy are $1 \%$ and $10 \%$, respectively.

Nitric oxide (NO) and total nitrogen oxides $\left(\mathrm{NO}_{y}\right)$ were measured by a commercial instrument (Model T200U, Advanced Pollution Instrumentation (API), USA), equipped with an externally placed molybdenum oxide catalytic converter. Nitrogen dioxide $\left(\mathrm{NO}_{2}\right)$ was monitored using cavityattenuated phase-shift spectroscopy, which is highly selective for true $\mathrm{NO}_{2}$ (Model T500U, API, USA). $\mathrm{O}_{3}$ was measured by a UV photometric analyzer (Model T400, API, USA). CO was measured by a gas filter correlation, nondispersive infrared analyzer (Model 300EU, API, USA). 
$\mathrm{SO}_{2}$ was measured by an ultraviolet fluorescence analyzer (Model 43C, Thermo Electron Corporation, USA). The fineparticle $\left(\mathrm{PM}_{2.5}\right)$ mass concentration was measured using a Synchronized Hybrid Ambient Real-time Particulate monitor (SHARP; Thermo Scientific Model 5030). Inorganic watersoluble ions (e.g., $\mathrm{NO}_{3}^{-}, \mathrm{SO}_{4}^{2-}, \mathrm{NH}_{4}^{+}$) in $\mathrm{PM}_{2.5}$ together with acid and alkaline gases (e.g., $\mathrm{HNO}_{3}, \mathrm{NH}_{3}$ ) were detected by a Monitor for AeRosols and GAses (MARGA, ADI20801, Applikon-ECN, the Netherlands). The particle number size distributions (5-10000 nm) were measured by a Wide-range Particle Spectrometer (WPS, Model 1000XP, MSP Corporation, USA) and were used to calculate the aerosol surface area density with the assumption that the particles are of a spherical shape. Methane and $\mathrm{C}_{2}-\mathrm{C}_{10}$ non-methane hydrocarbons (NMHCs) were measured by taking ambient air samples in stainless-steel canisters on selected days, followed by chemical analysis by GC-FID/ECD/MS in the laboratory of University of California at Irvine (Simpson et al., 2010). $\mathrm{C}_{1}-\mathrm{C}_{8}$ carbonyl compounds were observed offline by absorbing ambient air into a 2,4-DNPH sorbent cartridge followed by HPLC analysis (Yang et al., 2018). Meteorological data including temperature, relative humidity $(\mathrm{RH})$, pressure, and wind speed and direction were provided by the Taishan National Reference Climatological Station. Photolysis frequency of $\mathrm{NO}_{2}\left(J\left(\mathrm{NO}_{2}\right)\right)$ was monitored by a filter radiometer (Meteorologie Consult GmbH, Germany), and the measurements were only available during the spring campaign. All of these techniques have been successfully used in many previous studies, where details of the operation, quality assurance, and quality control procedures can be found (e.g., D. Li et al., 2018; Wen et al., 2018).

The photolysis frequencies of $J\left(\mathrm{NO}_{2}\right), J(\mathrm{HONO})$, and $J\left(\mathrm{O}^{1} \mathrm{D}\right)$ were computed with the NCAR Tropospheric Ultraviolet and Visible (TUV) radiation model (http://cprm.acom.ucar.edu/Models/TUV/Interactive_TUV/, last access: 16 March 2020), with the $\mathrm{O}_{3}$ column density obtained from the Total Ozone Mapping Spectrometer (TOMS, data available at https://giovanni.gsfc.nasa.gov/ giovanni/\#service $=$ TmAvMp $\&$ starttime $=\&$ endtime $=, \quad$ last access: 16 March 2020). In spring when the measured $J\left(\mathrm{NO}_{2}\right)$ was available, the calculated $J(\mathrm{HONO})$ and $J\left(\mathrm{O}^{1} \mathrm{D}\right)$ were scaled with the ratio of measured $J\left(\mathrm{NO}_{2}\right)$ to calculated $J\left(\mathrm{NO}_{2}\right)$. In winter, without direct observations of $J\left(\mathrm{NO}_{2}\right)$, the TUV-calculated $J$ values were approximated by multiplying the average ratio of measured $J\left(\mathrm{NO}_{2}\right)$ to calculated $J\left(\mathrm{NO}_{2}\right)$ obtained in spring (i.e., 0.7). It should be noted that such estimation of $J$ values is subject to some uncertainties, especially for those in winter, when direct $J\left(\mathrm{NO}_{2}\right)$ measurements were unavailable. Nonetheless, scaling the TUV-calculated clear-sky $J$ values with the same ratio should not alter the major conclusion of this study regarding the impacts of $\mathrm{HONO}$ photolysis on the $\mathrm{HO}_{x}$ sources and atmospheric oxidation capacity.

\subsection{Lagrangian particle dispersion model}

A Lagrangian particle dispersion model (LPDM, WRFFLEXPART v3.3) was utilized to investigate the provenance and trajectory of the air masses sampled at Mt. Tai. The Weather Research and Forecasting (WRF) Model, driven by the NCEP FNL reanalysis data (https://rda.ucar. edu/datasets/ds083.3/index.html\#sfol-fw?g=201608, last access: 9 March 2020), was run to produce the high-spatialresolution meteorological field. The horizontal resolution of the WRF model simulations was $20 \mathrm{~km}$, and the vertical direction was divided into 30 layers under $100 \mathrm{hPa}$, including 18 layers below an altitude of $2 \mathrm{~km}$. In the LPDM simulations, 3000 particles were released for $3 \mathrm{~d}$ backward trajectories from the observational station at an altitude of $1400 \mathrm{~m}$ a.g.l. The domain was in the range of $25.5-43.5^{\circ} \mathrm{N}$, $105-126^{\circ} \mathrm{E}$ with $0.1^{\circ} \times 0.1^{\circ}$ grids. The residence time of particles for a thickness of $100 \mathrm{~m}$ above the surface in all grid cell was calculated as the "footprint" retroplume, which indicated the distribution of probability or residence time of a simulated air mass at the surface level. This method has been widely applied in previous studies (Stohl et al., 2003; Ding et al., 2009; Pan et al., 2014).

\subsection{Chemical box model}

A chemical box model was used to simulate the in situ tropospheric oxidation chemistry and quantify the contributions of HONO to the $\mathrm{OH}$ source and atmospheric oxidative capacity. It was set up based on the MCM (v3.3.1), a nearly explicit chemical mechanism describing the degradation of 143 primary volatile organic compounds (VOCs) in addition to the latest inorganic reactions (Jenkin et al., 2003; Saunders et al., 2003). The model was constrained with the measured concentrations of $\mathrm{NO}, \mathrm{NO}_{2}, \mathrm{CO}, \mathrm{SO}_{2}, \mathrm{O}_{3}$, VOCs, and carbonyls as well as the meteorological conditions at a time interval of $5 \mathrm{~min}$. For VOCs and carbonyls for which the measurements were not in real time, the high-resolution data were approximated as follows. During the daytime when multiple VOC and carbonyl samples were available, the measurement data were interpolated to a time resolution of $5 \mathrm{~min}$. For the period when measurement data were unavailable, the VOC concentrations (except for isoprene) were estimated with the real-time $\mathrm{CO}$ data by assuming a linear regression relationship between VOCs and CO (note that the regression was established with the available measurement data of VOCs and $\mathrm{CO})$. The same method was applied for isoprene and carbonyls, but ambient temperature was used instead of $\mathrm{CO}$ for isoprene, and multi-linear regression with $\mathrm{CO}$ and $\mathrm{O}_{3}$ was used for carbonyls to account for the primary and secondary sources of carbonyls (Yang et al., 2018; Xue et al., 2016). Such approximation may be subject to some uncertainties but should not significantly interfere in the estimation of the role of HONO photolysis in OH sources (Yang et al., 2018). The model computed the major primary production rates of $\mathrm{RO}_{x}$ 
radicals $\left(\mathrm{RO}_{x}=\mathrm{OH}+\mathrm{HO}_{2}+\mathrm{RO}_{2}\right)$, including photolysis of $\mathrm{O}_{3}$, HONO, HCHO and other oxygenated VOCs (OVOCs), and the ozonolysis reactions of unsaturated VOCs (Xue et al., 2016). Also calculated by the model was the AOC by OH, which is defined here as the sum reaction rate of $\mathrm{OH}$ with $\mathrm{NO}, \mathrm{NO}_{2}, \mathrm{SO}_{2}, \mathrm{CO}$, and VOCs $\left(\mathrm{AOC}=\Sigma\left(k_{\mathrm{OH}}[\mathrm{OH}][\mathrm{Xi}]\right)\right.$ : [Xi] is the concentration of the individual reactant species, and $K_{\mathrm{OH}}$ is the rate coefficient of $\mathrm{OH}$ with $\mathrm{Xi}$ ). The model simulations were performed for the two campaigns, and a $4 \mathrm{~d}$ pre-run was made with constraints of campaign-average data to facilitate the model to a chemical steady state for the unconstrained species. Two model scenarios with and without the measured HONO constraints were constructed to assess the contribution of the unknown $\mathrm{HONO}$ sources to the $\mathrm{OH}$ chemistry (note that the model only contained the homogeneous source of HONO). This model has been extensively adopted to simulate the radical chemistry and ozone formation in our previous studies (Xue et al., 2014, 2016; Yang et al., 2018).

\section{Results and discussion}

\subsection{Concentration levels and temporal variations}

Table 1 summarizes the statistics of major trace gases, $\mathrm{PM}_{2.5}$, and meteorological parameters observed at Mt. Tai during the two campaigns, and the detailed time series of HONO and related species are shown in Figs. S1-S2. The atmospheric conditions at Mt. Tai were dominated by cold and dry weather (especially in winter with average $( \pm$ standard deviation; SD) temperature and $\mathrm{RH}$ of $-5.2 \pm 3.8^{\circ} \mathrm{C}$ and $48 \pm 20 \%$, respectively) as well as relatively lower concentrations of air pollutants. This was due to the high elevation of the station, which is primarily located in the lower FT and/or upper PBL during the measurement periods. The sampled air masses at Mt. Tai were rather chemically aged, as indicative of the low $\mathrm{NO}_{x} / \mathrm{NO}_{y}$ ratios with average values $( \pm \mathrm{SD})$ of $0.45 \pm 0.21$ and $0.25 \pm 0.19$ in winter and spring, respectively. The average concentrations of $\mathrm{NO}_{x}(4.64 \pm 3.78 \mathrm{ppbv}), \mathrm{SO}_{2}(3.8 \pm 4.2 \mathrm{ppbv})$, and $\mathrm{PM}_{2.5}$ $\left(41.1 \pm 28.2 \mu \mathrm{g} \mathrm{m}^{-3}\right)$ in winter were significantly higher than those in spring $\left(2.18 \pm 2.09 \mathrm{ppbv}\right.$ for $\mathrm{NO}_{x}, 1.6 \pm 1.6 \mathrm{ppbv}$ for $\mathrm{SO}_{2}$, and $33.7 \pm 26.7 \mu \mathrm{g} \mathrm{m}^{-3}$ for $\mathrm{PM}_{2.5}$ ), while an opposite seasonal pattern was found for $\mathrm{O}_{3}(49 \pm 12 \mathrm{ppbv}$ in winter vs. $63 \pm 14 \mathrm{ppbv}$ in spring). The ambient levels of HONO were comparable in both seasons, with average mixing ratios $( \pm S D)$ of $0.15 \pm 0.15$ and $0.13 \pm 0.15$ ppbv in winter and spring, respectively. Despite the relatively low average concentration levels, spikes in $\mathrm{HONO}$ (and $\mathrm{NO}_{x}, \mathrm{NO}_{y}$, $\mathrm{CO}$, and $\mathrm{PM}_{2.5}$ ) concentrations were frequently encountered throughout the measurement periods (see Figs. S1-S2 in the Supplement), indicating the transport of polluted plumes to the mountaintop. The maximum HONO mixing ratios were recorded at 1.14 and $3.23 \mathrm{ppbv}$ in winter and spring, respec- tively. The above inspection of data reveals the overall moderate HONO concentration levels as well as the frequent occurrence of HONO-laden plumes in the upper PBL and lower FT of the NCP region.

Table 2 compares the HONO concentration levels at Mt. Tai with those measured at various surface sites as well as in the high-elevation atmosphere around the world. Obviously, the HONO concentrations at Mt. Tai were significantly lower than those observed at the polluted surface sites in China. For example, the ambient HONO levels at Mt. Tai were approximately an order of magnitude lower than those at urban or suburban sites in the NCP and Pearl River Delta (PRD) regions. This is within the realm of expectation considering the height of Mt. Tai and the short lifetime of HONO. A detailed comparison against the measurement results at a nearby urban site will be made in Sect. 3.2 to infer the vertical distribution of HONO in this region. Despite the lower absolute levels, a noteworthy result is that the $\mathrm{HONO} / \mathrm{NO}_{2}$ ratios at Mt. Tai $(0.059 \pm 0.091$ in winter and $0.072 \pm 0.080$ in spring $)$ are well within the reported ranges (0.041-0.093) obtained at these surface sites (Su et al., 2008b; X. Li et al., 2012; Wang et al., 2017; D. Li et al., 2018; Y. Liu et al., 2019), implying that $\mathrm{NO}_{2}$ might be the key factor governing the regional distribution (or formation) of HONO. Another important finding from the comparison is that the HONO concentrations at Mt. Tai are substantially higher than those measured from the high-elevation atmosphere, e.g., Whiteface Mountain, USA (Zhou et al., 2007); Summit, Greenland (Dibb et al., 2002); Hohenpeissenberg, Germany (Acker et al., 2006); Brocken, Germany (Acker et al., 2001); and aboard research aircraft over the North Atlantic Ocean (Ye et al., 2016), northern Michigan (Zhang et al., 2009), and the southeastern USA (Ye et al., 2018). This demonstrates the higher pollution levels of HONO in the upper PBL and lower FT in the NCP region, which may further lead to a stronger supply of $\mathrm{OH}$ radicals and higher atmospheric oxidation capacity in the highelevation atmosphere. It is very important to pin down the sources of the elevated HONO and fully evaluate their impacts on $\mathrm{OH}$ radicals and AOC in the upper PBL and lower FT of the NCP region, which will be detailed in the following sections.

Figure 2 shows the average diurnal variation patterns of HONO and related parameters during the two measurement campaigns. Overall, most pollutants including $\mathrm{NO}_{2}, \mathrm{NO}_{y}$, $\mathrm{CO}, \mathrm{O}_{3}$, and $\mathrm{PM}_{2.5}$ showed well-defined diurnal profiles with a daytime concentration peak, compared to lower levels during the nighttime (note that the exact peak time varied among the individual pollutants with different lifetimes and photochemical behaviors). This can be explained by the evolution of the PBL, mountain-valley breeze, and atmospheric photochemistry (Sun et al., 2016). Similar diurnal patterns were also found for HONO, showing noontime concentration peaks with relatively lower mixing ratios during the night in both seasons. Such a pattern is quite different from those determined by most previous studies at the ground level, which 
Table 1. Statistics (average \pm standard deviation) of trace gases, $\mathrm{PM}_{2.5}$, and meteorological parameters measured at Mt. Tai in winter 2017 and spring 2018.

\begin{tabular}{lrrr|rrr}
\hline \multirow{2}{*}{ Parameter } & \multicolumn{3}{c}{ Winter 2017 } & \multicolumn{3}{c}{ Spring 2018 } \\
\cline { 2 - 7 } & All data & Daytime & Nighttime & All data & Daytime & Nighttime \\
\hline $\mathrm{HONO}(\mathrm{ppb})$ & $0.15 \pm 0.15$ & $0.18 \pm 0.15$ & $0.11 \pm 0.14$ & $0.13 \pm 0.15$ & $0.16 \pm 0.18$ & $0.09 \pm 0.12$ \\
$\mathrm{NO}_{2}(\mathrm{ppb})$ & $3.59 \pm 2.98$ & $4.21 \pm 3.06$ & $2.92 \pm 2.75$ & $2.00 \pm 1.91$ & $2.29 \pm 1.99$ & $1.72 \pm 1.77$ \\
$\mathrm{NO}(\mathrm{ppb})$ & $0.77 \pm 1.19$ & $1.23 \pm 1.32$ & $0.05 \pm 0.04$ & $0.26 \pm 0.35$ & $0.39 \pm 0.40$ & $0.09 \pm 0.12$ \\
$\mathrm{NO}_{x}(\mathrm{ppb})$ & $4.64 \pm 3.78$ & $5.62 \pm 4.05$ & $2.99 \pm 2.53$ & $2.18 \pm 2.09$ & $2.58 \pm 2.26$ & $1.77 \pm 1.81$ \\
$\mathrm{NO}_{y}(\mathrm{ppb})$ & $9.89 \pm 7.25$ & $11.30 \pm 6.67$ & $8.61 \pm 7.22$ & $9.61 \pm 7.31$ & $10.61 \pm 7.62$ & $8.63 \pm 6.84$ \\
$\mathrm{O}_{3}(\mathrm{ppb})$ & $49 \pm 12$ & $49 \pm 12$ & $48 \pm 12$ & $63 \pm 14$ & $64 \pm 14$ & $63 \pm 14$ \\
$\mathrm{PM}_{2.5}\left(\mu \mathrm{g} \mathrm{m}{ }^{-3}\right)$ & $41.1 \pm 28.2$ & $41.9 \pm 24.3$ & $40.3 \pm 31.7$ & $33.7 \pm 26.7$ & $35.9 \pm 26.3$ & $31.6 \pm 27.0$ \\
$\mathrm{SO}_{2}(\mathrm{ppb})$ & $3.8 \pm 4.2$ & $3.8 \pm 2.0$ & $3.8 \pm 5.6$ & $1.6 \pm 1.6$ & $2.1 \pm 1.8$ & $1.1 \pm 1.2$ \\
$\mathrm{CO}(\mathrm{ppb})$ & $376 \pm 193$ & $393 \pm 187$ & $358 \pm 197$ & $382 \pm 161$ & $395 \pm 162$ & $170 \pm 159$ \\
$\mathrm{RH}_{(\%)}$ & $48 \pm 20$ & $48 \pm 20$ & $48 \pm 21$ & $60 \pm 26$ & $55 \pm 24$ & $66 \pm 27$ \\
${\mathrm{Temperature}\left({ }^{\circ} \mathrm{C}\right)}^{-5.2 \pm 3.8}$ & $-4.6 \pm 3.8$ & $-5.7 \pm 3.6$ & $4.3 \pm 6.4$ & $5.1 \pm 6.5$ & $3.2 \pm 6.0$ \\
Pressure (hpa) & $849.0 \pm 0.3$ & $849.1 \pm 0.3$ & $849.2 \pm 0.3$ & $846.9 \pm 0.3$ & $847.1 \pm 0.3$ & $846.7 \pm 0.3$ \\
\hline
\end{tabular}

Daytime period: 06:00-18:00 LT. Nighttime period: 18:00-06:00 LT.

generally show higher nighttime concentrations but with a daytime trough (Lee et al., 2016; D. Li et al., 2018; Y. Liu et al., 2019; Fu et al., 2019). The noontime HONO maximum (e.g., $\sim$ 11:00-15:00 LT) at Mt. Tai suggested the potential upslope transport of HONO to the mountaintop and/or the presence of "additional" daytime sources. The almost coincident noontime concentration peak of $\mathrm{CO}$ (e.g., $~ 12: 00$ 15:00 LT) confirmed the upslope transport of boundary layer air to the mountaintop. We also examined the diurnal variations of $\mathrm{HONO} / \mathrm{NO}_{2}$, the ratio commonly used to indicate the efficiency of HONO formation from the reactions involving $\mathrm{NO}_{2}$ (Yu et al., 2009). From Fig. 2c, the $\mathrm{HONO} / \mathrm{NO}_{2}$ ratio shows an increasing trend throughout the nighttime together with an extra peak during the midday in both seasons. This indicates nighttime HONO formation and accumulation from the heterogeneous reactions of $\mathrm{NO}_{2}$ as well as the presence of some "additional" daytime sources. The higher daytime $\mathrm{HONO} / \mathrm{NO}_{2}$ ratios in spring than in winter suggest the action of photo-enhanced heterogeneous formation of HONO. The daytime HONO sources will be diagnosed via a detailed PSS calculation in Sect. 3.3.

\subsection{Potential transport by PBL evolution and mountain-valley breeze}

In this section, we compare our observations at Mt. Tai with the recent year-round measurement results obtained at a surface site in Ji'nan to infer the vertical gradient of HONO over the NCP region, and we examine the vertical transport of HONO with the LPDM modeling. The surface site is located in the downtown of Ji'nan, which is about $60 \mathrm{~km}$ to the north of Mt. Tai (Fig. 1), and the measurement data have been reported by D. Li et al. (2018). It should be noticed that both measurements were not conducted at the same time, and only the average conditions of $\mathrm{HONO}$ and $\mathrm{NO}_{2}$ in the same season were compared here.

Figure 3 presents the average diurnal variations of $\mathrm{HONO}$, $\mathrm{NO}_{2}$, and $\mathrm{HONO} / \mathrm{NO}_{2}$ at both the surface and mountaintop in winter and spring. Several interesting aspects are clearly illustrated in the figure. First, the diurnal variation patterns are distinct between the surface and the mountaintop. HONO showed higher concentrations at nighttime and lower levels during the day at the surface, which is opposite to the profile at the mountaintop. Second, the $\mathrm{HONO}$ and $\mathrm{NO}_{2}$ concentrations at the surface were overall almost an order of magnitude higher than those at Mt. Tai, but the vertical gradient (as indicative of the mountaintop/surface (M/S) concentration ratio) showed a clear diurnal dependence. The $\mathrm{M} / \mathrm{S}$ ratios of HONO at nighttime (18:00-6:00 LT; with averages of $0.05 \pm 0.01$ and $0.07 \pm 0.02$ in winter and spring, respectively) were significantly lower than those during midday (11:0015:00 LT; $0.28 \pm 0.04$ and $0.23 \pm 0.03$ ). This is also the case for $\mathrm{NO}_{2}$ and should be ascribed to the efficient mixing within the PBL and upslope transport driven by the valley breeze during the daytime. Third, although the $\mathrm{HONO} / \mathrm{NO}_{2}$ ratios were almost comparable at both the surface and Mt. Tai during the night, the daytime ratios were significantly higher at the mountaintop $(0.065 \pm 0.093$ and $0.093 \pm 0.094)$ than at the surface $(0.047 \pm 0.090$ and $0.052 \pm 0.040)$. This implies enhanced $\mathrm{HONO}$ formation from the $\mathrm{NO}_{2}$-involved sources at the mountaintop, especially in spring (see Fig. 3).

Can the PBL mixing and mountain-valley breeze transport HONO from the ground level to the mountaintop with an altitude of $\sim 1.5 \mathrm{~km}$, given its quite short lifetime? The vertical transport distance $(\sigma)$ driven by the turbulent diffusion can be estimated by the following Eq. (2) (Jacob, 1999):

$\sigma=\left(2 K_{z} \tau_{\mathrm{HONO}}\right)^{1 / 2}$ 

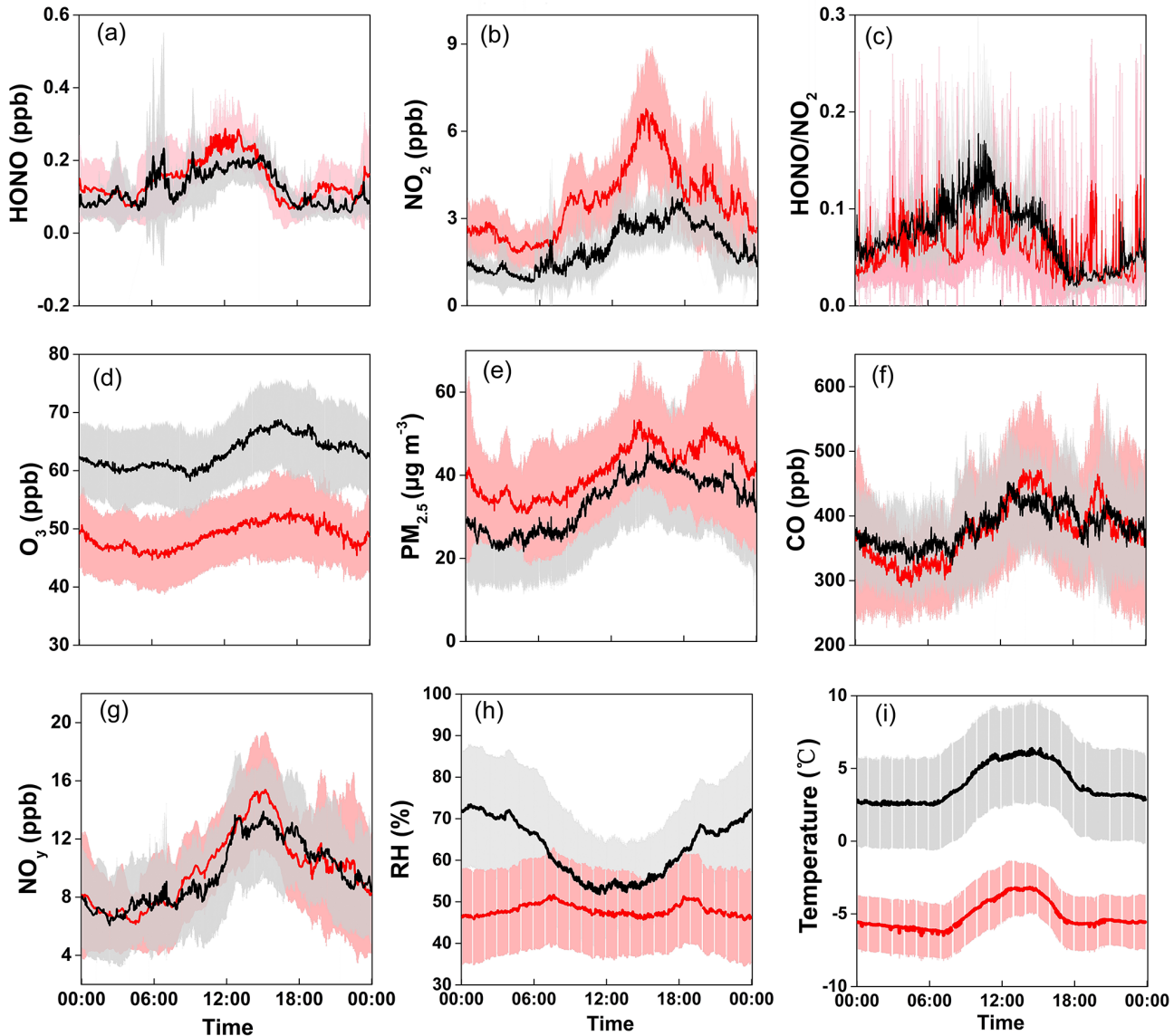

Figure 2. Average diurnal variations of (a) $\mathrm{HONO}$, (b) $\mathrm{NO}_{2}$, (c) $\mathrm{HONO} / \mathrm{NO}_{2}$, (d) $\mathrm{O}_{3}$, (e) $\mathrm{PM}_{2.5}$, (f) $\mathrm{CO}$, (g) $\mathrm{NO}$, (h) $\mathrm{RH}$, and (i) temperature in winter (red) and spring (black) at Mt. Tai. Shaded area indicates half of the standard deviation of the measurement data.
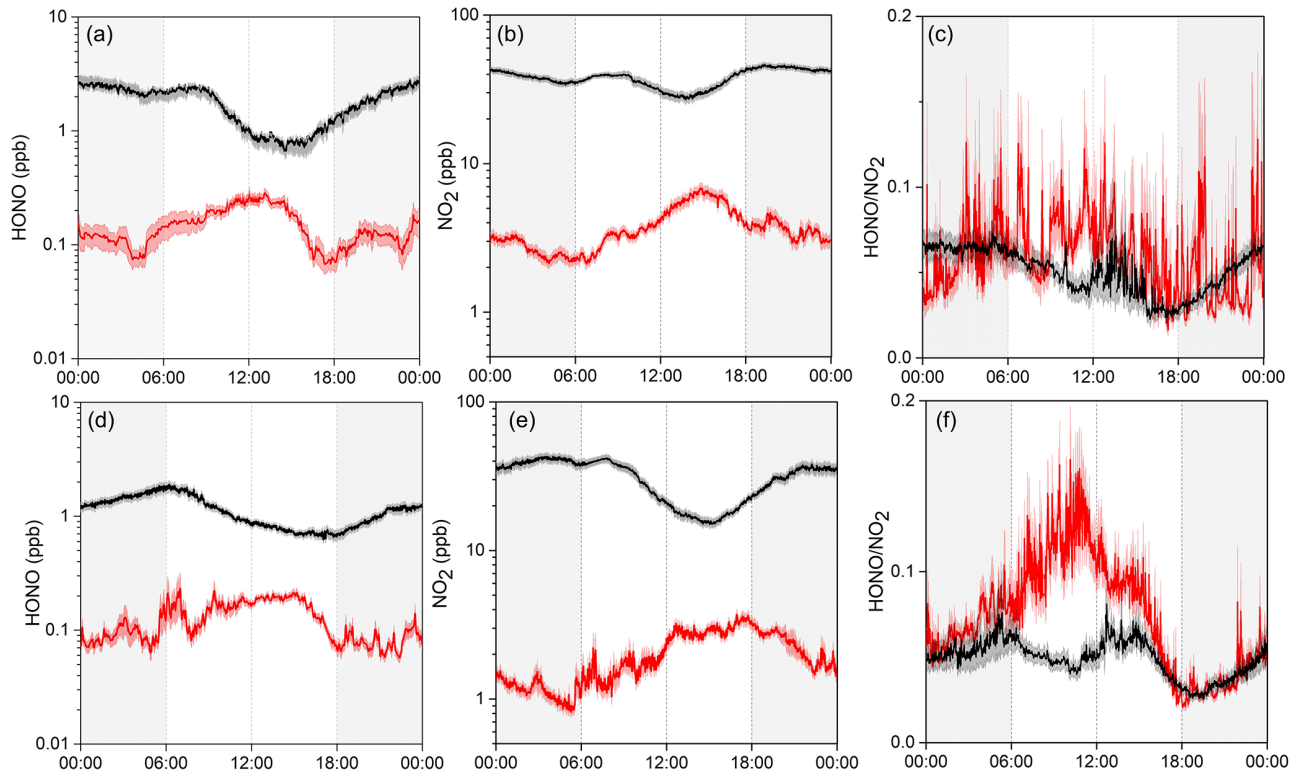

Figure 3. Comparison of the average diurnal variations of $\mathrm{HONO}, \mathrm{NO}_{2}$, and $\mathrm{HONO} / \mathrm{NO}_{2}$ at Mt. Tai (red) and in urban Ji'nan (black) in winter (upper panel) and spring (lower panel). Shaded area indicates the standard error of measurement data. 
Table 2. Comparison of ambient HONO concentration levels observed at Mt. Tai with previous studies at both surface and high-elevation sites.

\begin{tabular}{|c|c|c|c|c|}
\hline \multirow{2}{*}{ Type } & \multirow{2}{*}{ Site Location } & \multirow{2}{*}{ Period } & HONO (ppb) & \multirow{2}{*}{ References } \\
\hline & & & Mean \pm SD & \\
\hline \multirow{13}{*}{ 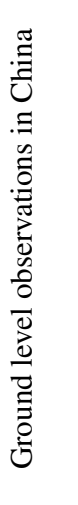 } & Beijing, China (urban) & Sep-Oct 2015 & $2.27 \pm 1.82$ & Wang et al. (2017) \\
\hline & Beijing, China (urban) & 3-27 Jan 2016 & $1.05 \pm 0.89$ & Wang et al. (2017) \\
\hline & Beijing, China (urban) & Apr-May 2016 & $1.05 \pm 0.95$ & Wang et al. (2017) \\
\hline & Beijing, China (urban) & Jun-July 2016 & $1.38 \pm 0.90$ & Wang et al. (2017) \\
\hline & Ji'nan, China (urban) & Sep-Nov 2015 & $0.78 \pm 0.60$ & D. Li et al. (2018) \\
\hline & Ji'nan, China (urban) & Dec 2015-Feb 2016 & $1.75 \pm 1.62$ & D. Li et al. (2018) \\
\hline & Ji'nan, China (urban) & Mar-May 2016 & $1.16 \pm 0.90$ & D. Li et al. (2018) \\
\hline & Ji'nan, China (urban) & Jun-Aug 2016 & $1.12 \pm 0.93$ & D. Li et al. (2018) \\
\hline & Wangdu, China (rural) & Jun-Jul 2014 & $0.91 \pm 0.48$ & Y. Liu et al. (2019) \\
\hline & Guangzhou, China (urban) & Jun 2006 & 2.80 & Qin et al. (2009) \\
\hline & Xinken, China (rural) & 13 Oct-2 Nov 2004 & 1.20 & Su et al. (2008b) \\
\hline & Back Garden, China (rural) & Jul 2006 & 0.76 & X. Li et al. (2012) \\
\hline & Shanghai, China (urban) & Oct 2004-Jan 2005 & $1.1 \pm 1.0$ & Cui et al. (2018) \\
\hline \multirow{12}{*}{ 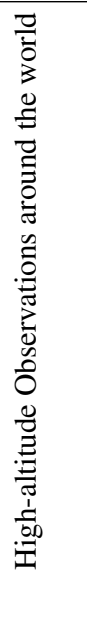 } & Whiteface Mountain, USA (1483 m a.s.1.) & 14 Jun-20 Jul 1999 & 0.046 & Zhou et al. (2007) \\
\hline & Summit, Greenland (3200 m a.s.1.) & 2 Jul-4 Jul 1999 & 0.009 & Dibb et al. (2002) \\
\hline & & 3-12 Jul 2002 & 0.039 & Acker et al. (2006) \\
\hline & Hohenpeissenberg, Germany (980 m a.s.I.) & 29 Jun-14 Jul 2004 & 0.063 & Acker et al. (2006) \\
\hline & Brocken, Germany (1142 m a.s.1.) & 19 Jun-4 Jul 1999 & 0.056 & Acker et al. (2001) \\
\hline & North Atlantic Ocean $(<2500 \mathrm{ma} \sigma 1)$ & 5 Jul 2013 & $0.011 \pm 0.002$ & Ye et al. (2016) \\
\hline & North Atiantic Ucean (<2500 m a.g.I.) & 8 Jul 2013 & $0.009 \pm 0.002$ & Ye et al. (2016) \\
\hline & Northern Michigan (1000-1900 m.) & 30 Jul-6 Aug 2007 & 0.009 & Zhang et al. (2009) \\
\hline & Northern Italy (300-1000 m a.g.1.) & 12 Jul 2012 & $\sim 0.15$ & Li et al. (2014) \\
\hline & Southeastern USA (> 1500 m a.g.1.) & 1 Jun-15 Jul 2013 & $0.006 \pm 0.003$ & Ye et al. (2018) \\
\hline & Mt Tai China $(1534$ & Nov-Dec 2017 & $0.15 \pm 0.15$ & This study \\
\hline & VIt. Ia1, Cnina (1534 m a.s.I.) & Mar-Apr 2018 & $0.13 \pm 0.15$ & This study \\
\hline
\end{tabular}

where $K_{z}$ is the turbulent diffusion coefficient, and $\tau_{\mathrm{HONO}}$ is the chemical lifetime of HONO. In the early morning when the boundary layer is stable, $K_{z}$ is usually within the range of $10^{2} \sim 10^{5} \mathrm{~cm}^{2} \mathrm{~s}^{-1}$ and increases with the temperature (Zhang et al., 2009). Assuming an overall $\tau_{\mathrm{HONO}}$ of $60 \mathrm{~min}$ in the early morning (corresponding to a $J(\mathrm{HONO})$ of $2.8 \times 10^{-4} \mathrm{~s}^{-1}$ ), the vertical transport distance of the groundlevel HONO is estimated in the range of 9-268 m, far below the altitude of Mt. Tai. This explains the huge difference in the HONO concentrations between the surface site and the mountaintop in the early morning and during the nighttime. Around noontime, the PBL has been developed and $K_{z}$ is generally on the order of $10^{6} \mathrm{~cm}^{2} \mathrm{~s}^{-1}$ (Zhang et al., 2009). Adopting a median value of $K_{z}\left(5 \times 10^{6} \mathrm{~cm}^{2} \mathrm{~s}^{-1}\right)$ and $\tau_{\mathrm{HONO}}$ ( $25 \mathrm{~min}$; refer to Sect. 3.3 for the lifetime estimation), the maximum transport distance of HONO can be up to $1200 \mathrm{~m}$, which is still below the peak of Mt. Tai. If we further consider the mountain-valley breeze, by adopting a mean upslope wind speed of $1 \mathrm{~m} \mathrm{~s}^{-1}$ (Kalthoff et al., 2000; Wang et al., 2015), the transport height of HONO by the valley breeze is estimated to be $1500 \mathrm{~m}$. Note that the transported HONO from the ground level may be subject to extensive dilution and more photolysis at higher altitudes. Therefore, the PBL evolution and valley breeze should play an important role in the regional transport of HONO in the mountainous areas.

The LPDM modeling results also support the upslope transport of surface pollution to Mt. Tai. Figure 4 shows the average distributions of the footprint retroplume of the $3 \mathrm{~d}$ backward trajectories, computed by the WRF-FLEXPART model, arriving at Mt. Tai during both daytime and nighttime. During the night and early morning (02:00-8:00 LT), obviously, the air masses sampled at Mt. Tai mainly originated from long-range transport and were less affected by the PBL air from the NCP region (Fig. 4a and c). This can be explained by the fact that Mt. Tai is in the free troposphere (or residual layer) and under the influence of a downslope mountain breeze during the nighttime. In comparison, the air masses reaching Mt. Tai in the afternoon (12:00-18:00 LT) 
primarily came from the boundary layer in the nearby regions (i.e., Ji'nan, Tai' an, and Ji'ning: major cities surrounding Mt. Tai; Fig. $4 \mathrm{~b}$ and d). Note that the footprint retroplume denotes the residence time of particles within the lowest $100 \mathrm{~m}$ near the surface. This demonstrates the efficient transport of regional surface air pollution to the mountaintop with the development of PBL and valley breeze.

\subsection{Daytime HONO sources}

Exploration of the potential daytime source has been a major objective of the recent HONO observational studies. Here we diagnose the possible daytime sources of HONO in the upper PBL and lower FT by performing a PSS analysis for the measurement data collected at Mt. Tai. According to the measurement-derived $J(\mathrm{HONO})$ (with noontime averages of $6.4 \pm 3.5$ and $9.5 \pm 3.2 \times 10^{-4} \mathrm{~s}^{-1}$ in winter and spring, respectively; see Fig. S3) and the model-simulated $\mathrm{OH}$ concentrations (with noontime averages of $2.5 \pm 0.7$ and $4.4 \pm 2.0 \times 10^{6}$ molecules $\mathrm{cm}^{-3}$; Fig. S3), the average lifetime of HONO was estimated as $25.7 \pm 1.4$ and $21.8 \pm 16.9 \mathrm{~min}$ during noontime (11:00-14:00 LT) in winter and spring, respectively. Given such short lifetimes, the air masses arriving at Mt. Tai at noon should facilitate a steady state for HONO. The PSS concentrations of HONO ([HONO $]_{p s s}$ ) can be deduced from Eq. (1) if we only take the homogeneous formation from $\mathrm{OH}+\mathrm{NO}$ reactions, $\mathrm{HONO}$ photolysis, and $\mathrm{OH}+\mathrm{HONO}$ reactions into account. Note that the $\mathrm{OH}$ concentrations were simulated with the observation-constrained MCM model as described in Sect. 2.4 (see Fig. S3 for detailed time series of $\mathrm{OH}$ ). The PSS approach has been widely used in previous studies (Zhou et al., 2002; Kleffmann et al., 2005; Elshorbany et al., 2012).

Figure 5 shows the campaign-average $[\mathrm{HONO}]_{\mathrm{pss}}$ at noontime and the comparison with the measured HONO concentrations in the two seasons. It is evident that the $[\mathrm{HONO}]_{\mathrm{pss}}$ was significantly lower than the measured data. On average, $[\mathrm{HONO}]_{\mathrm{pss}}$ only accounted for 18 and $12 \%$ of the ambient HONO levels at Mt. Tai in winter and spring (see Fig. S4), respectively, demonstrating the existence of strong HONO sources other than the homogeneous $\mathrm{OH}+\mathrm{NO}$ reactions. To maintain the observed HONO levels, an additional "source" is needed, and its source strength (hereafter referred to as $\mathrm{P}_{\text {other}}$ ) can be calculated from Eq. (3).

$$
\begin{aligned}
\mathrm{P}_{\mathrm{other}} & =[\mathrm{HONO}]_{\mathrm{obs}} \times J(\mathrm{HONO})+[\mathrm{HONO}]_{\mathrm{obs}} \\
& \times[\mathrm{OH}] \times K_{\mathrm{OH}+\mathrm{HONO}}-[\mathrm{NO}] \times[\mathrm{OH}] \times K_{\mathrm{OH}+\mathrm{NO}}
\end{aligned}
$$

In the present study, the $\mathrm{P}_{\text {other }}$ was calculated in the range of $0.01-1.24$ and $0.01-4.26 \mathrm{ppbh}^{-1}$, with average $( \pm \mathrm{SD})$ values of $0.45 \pm 0.25$ and $0.64 \pm 0.49 \mathrm{ppb} \mathrm{h}^{-1}$ in winter and spring, respectively. In comparison, the noontime $\mathrm{HONO}$ production rates from the $\mathrm{OH}+\mathrm{NO}$ reactions were $0.13 \pm$ 0.10 and $0.09 \pm 0.08 \mathrm{ppbh}^{-1}$, much lower than $\mathrm{P}_{\text {other. The }}$ additional source strengths of daytime HONO at Mt. Tai are much lower than those previously reported at the surface sites in Ji'nan (2.95 ppb h ${ }^{-1}$; D. Li et al., 2018), Beijing (1.83 $\mathrm{ppbh}^{-1}$; Hou et al., 2016), and Santiago, Chile (1.69 $\mathrm{ppb} \mathrm{h}^{-1}$; Elshorbany et al., 2009), and are comparable to those derived from the rural or mountain sites, such as Hohenpeissenberg ( $0.40 \mathrm{ppb} \mathrm{h}^{-1}$; Acker et al., 2006), Whiteface Mountain $\left(0.38 \mathrm{ppbh}^{-1}\right.$; Zhou et al., 2007), and a forest site in Jülich, Germany $\left(0.50 \mathrm{ppb} \mathrm{h}^{-1}\right.$; Kleffmann et al., 2005). Some studies have reported much lower $P_{\text {other values }}$ obtained from aircraft studies in Michigan $\left(0.057 \mathrm{ppb} \mathrm{h}^{-1}\right.$; Zhang et al., 2009) and in the southern USA $\left(0.17 \mathrm{ppbh}^{-1}\right.$; Ye et al., 2018).

Recent field and laboratory studies have proposed some potential sources that may help explain the observed higherthan-PSS daytime HONO levels. Among them, direct emissions from vehicle exhaust and soil microbiological processes, heterogeneous conversion of $\mathrm{NO}_{2}$ to $\mathrm{HONO}$ on surfaces, and photolysis of adsorbed and aqueous-phase nitrate are relatively well accepted to be relevant in the ambient atmosphere (Zhou et al., 2003; Su et al., 2011; VandenBoer et al., 2013; Y. Liu et al., 2019). It is believed that vehicle and soil emissions should be of minor importance at Mt. Tai, which is free from anthropogenic activities and soil surfaces. We thus diagnosed the potential action of heterogeneous formation of HONO on both ground and aerosol surfaces as well as photolysis of nitrate by examining the relationship between $\mathrm{P}_{\mathrm{other}}$ and a variety of indicators for the specific HONO sources. Such a correlation analysis method has been widely applied in many previous studies to identify the most likely additional daytime HONO source, despite the inherent uncertainty in the statistical approach (Su et al., 2008b; Lee et al., 2016; Lu et al., 2018).

Figure 6 shows the scatterplots of $\mathrm{P}_{\text {other }}$ against several HONO source indicators during the two campaigns. As illustrated in the figure, $\mathrm{P}_{\text {other }}$ shows weak correlation with $\mathrm{NO}_{2}$ (the commonly used indicator for the heterogeneous $\mathrm{NO}_{2}$-toHONO conversion on the ground surface, assuming that the ground surface density is uniform in the PBL), with correlation coefficients $(r)$ of 0.26 and 0.24 in winter and spring, respectively. This indicates that the heterogeneous reactions on the ground should not be the dominant HONO source at Mt. Tai. When the aerosol surface area density $\left((S / V)_{\mathrm{a}}\right)$ was included, the correlations were significantly improved (Fig. 6b and e), with $r$ values of 0.52 and 0.43 , respectively, for $\mathrm{P}_{\text {other }}$ and $\mathrm{NO}_{2} \times(S / V)_{\mathrm{a}}$ (an indicator of the heterogeneous $\mathrm{NO}_{2}$-to-HONO conversion on the aerosol surface). Furthermore, the correlations were further improved after $J\left(\mathrm{NO}_{2}\right)$ (an indicator of sunlight) was considered, with $r$ being 0.54 and 0.48 for $\mathrm{P}_{\text {other }}$ and $J\left(\mathrm{NO}_{2}\right) \times \mathrm{NO}_{2} \times(S / V)_{\mathrm{a}}$ (Fig. $6 \mathrm{c}$ and $\mathrm{f}$ ), respectively. These results suggest that the photoenhanced heterogeneous reactions of $\mathrm{NO}_{2}$ on the aerosol surface should be a significant daytime HONO source at Mt. Tai. This is different from most previous studies conducted at the ground level showing the dominant role of ground surface in heterogeneous HONO formation (Kleffmann et al., 

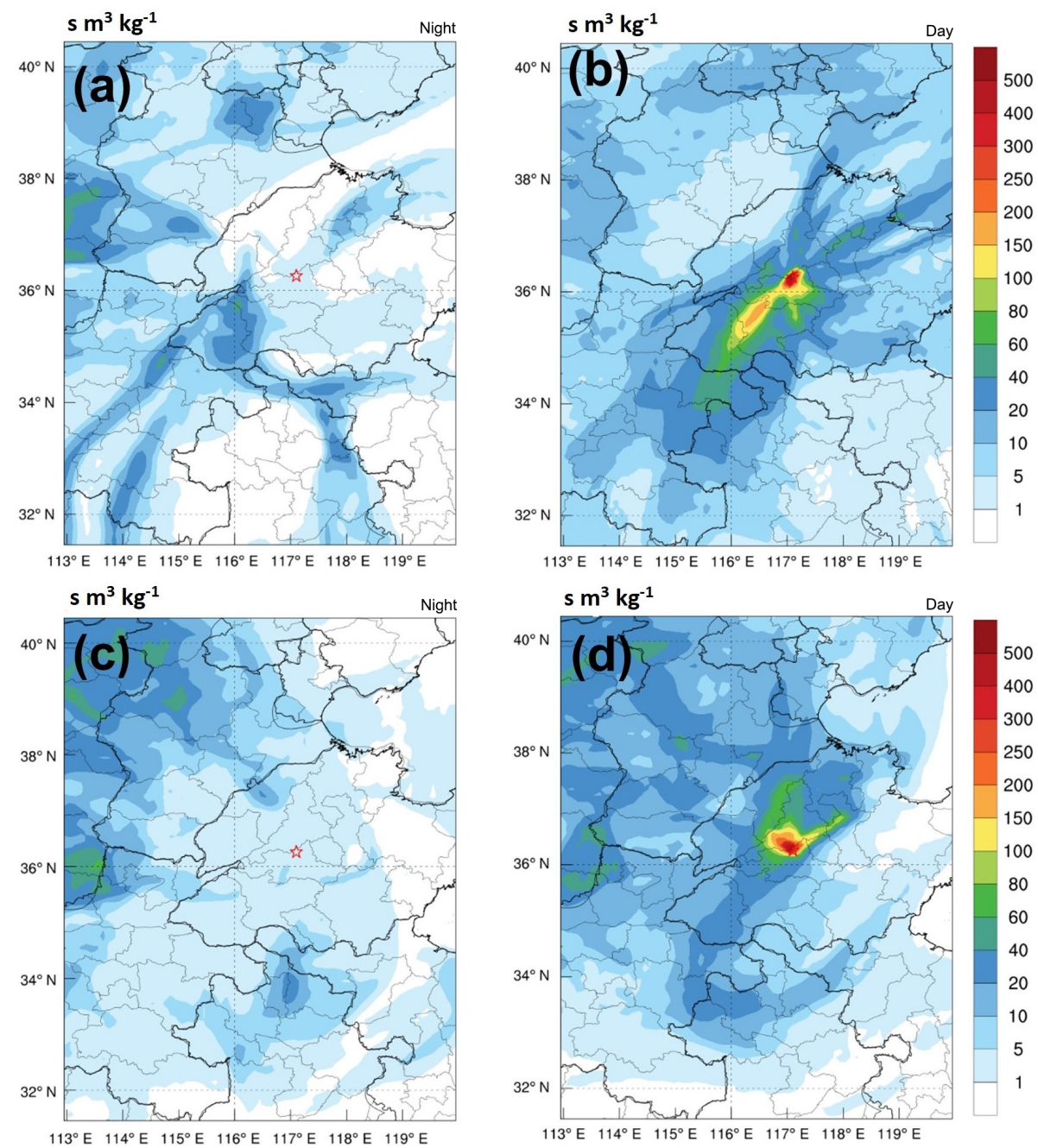

Figure 4. Average distribution of the "footprint" retroplume of the $3 \mathrm{~d}$ backward trajectory during (a) spring at nighttime (02:00-08:00 LT), (b) spring in the afternoon (12:00-18:00 LT), (c) winter at nighttime (02:00-8:00 LT), and (d) winter in the afternoon (12:00-18:00 LT). Note that the horizontal resolution is $0.1^{\circ}$.
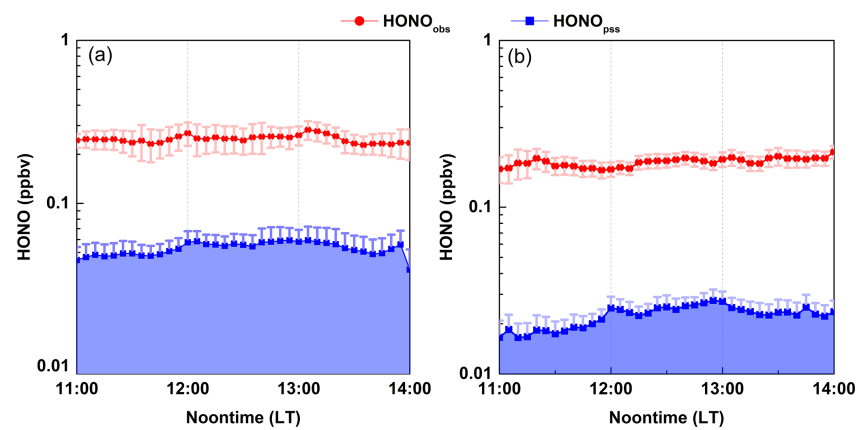

Figure 5. Average noontime $[\mathrm{HONO}]_{\mathrm{pss}}$ concentrations compared with the observed HONO concentrations in (a) winter and (b) spring. Shaded area indicates the level of [HONO $]_{\text {pss. }}$. Error bar indicates the standard error of data.
2003; Su et al., 2008a; Xu et al., 2015; D. Li et al., 2018), and it highlights the importance of the aerosol surface in HONO formation in the upper PBL and lower FT. Furthermore, Fig. S5 shows the relatively weak correlation between $\mathrm{P}_{\text {other }}$ and $J\left(\mathrm{NO}_{2}\right) \times p \mathrm{NO}_{3}^{-}$(the indicator for the photolysis of particulate nitrate), with $r$ of 0.17 and 0.03 , respectively, indicating that the nitrate photolysis is relatively insignificant to the ambient HONO at Mt. Tai.

There is the possible interference of peroxynitric acid (PNA; $\mathrm{HO}_{2} \mathrm{NO}_{2}$ ) for measuring $\mathrm{HONO}$ by the LOPAP especially in cold environments. While the LOPAP instrument has been extensively tested for a variety of interferences (Heland et al., 2001; Kleffmann and Wiesen, 2008), some recent studies have reported that it may be subject to positive interference from $\mathrm{HO}_{2} \mathrm{NO}_{2}$ (e.g., Legrand et al., 2014). Due to the thermal instability of $\mathrm{HO}_{2} \mathrm{NO}_{2}$, its interference is generally negligible at ambient temperatures at the ground level 

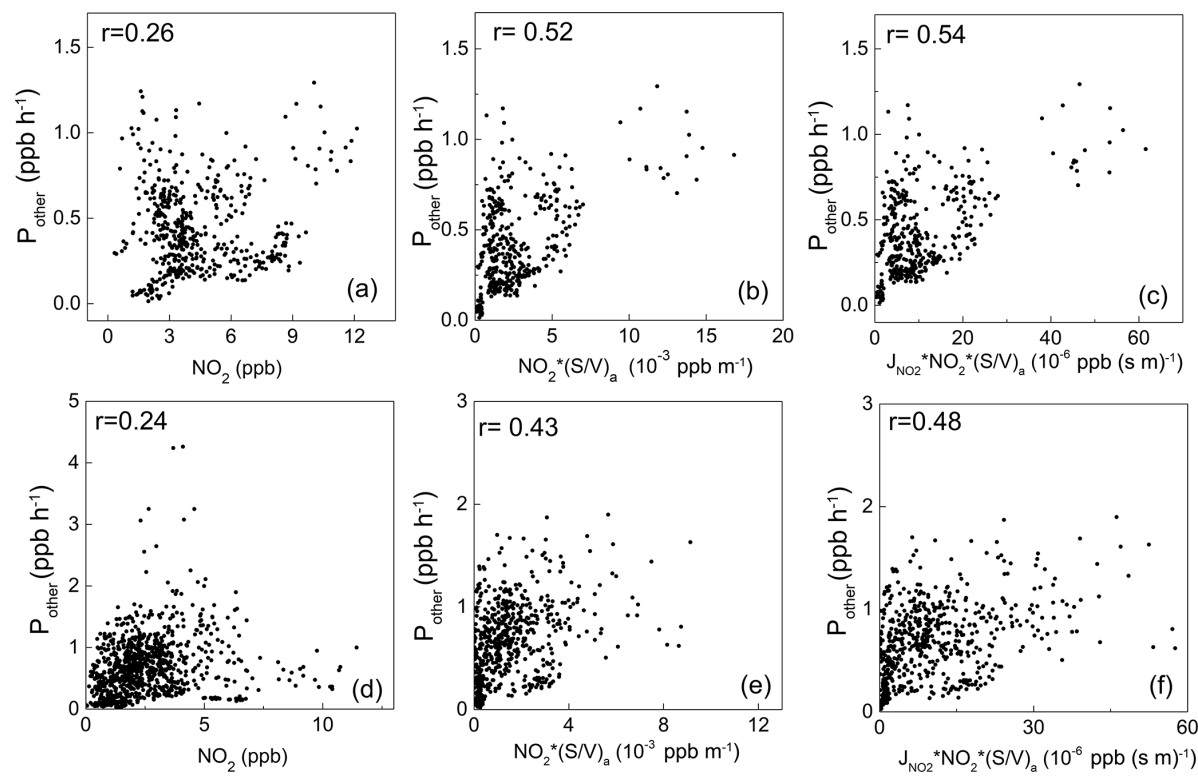

Figure 6. Scatterplots of the additional daytime HONO source strength $\left(\mathrm{P}_{\text {other }}\right)$ with $\mathrm{NO}_{2}, \mathrm{NO}_{2} \times(S / V)_{\mathrm{a}}$, and $J_{\mathrm{NO}_{2}} \times \mathrm{NO}_{2} \times(S / V)_{\mathrm{a}}$ in winter (a, b, c) and spring (d, e, f).

Table 3. Summary of major primary sources of $\mathrm{OH}, \mathrm{HO}_{2}$, and $\mathrm{RO}_{2}$ radicals simulated by the MCM model.

\begin{tabular}{|c|c|c|c|c|c|}
\hline \multicolumn{2}{|c|}{ Radical primary source ${ }^{\mathrm{a}}$} & \multicolumn{2}{|c|}{2017 winter } & \multicolumn{2}{|c|}{2018 spring } \\
\hline & & $\begin{array}{c}\text { Rate } \\
\left(\mathrm{ppbh}^{-1}\right)^{\mathrm{b}}\end{array}$ & $\begin{array}{l}\text { Proportion } \\
(\%)^{\mathrm{c}}\end{array}$ & $\begin{array}{c}\text { Rate } \\
\left(\mathrm{ppbh}^{-1}\right)^{\mathrm{b}}\end{array}$ & $\begin{array}{l}\text { Proportion } \\
(\%)^{\mathrm{c}}\end{array}$ \\
\hline \multirow{4}{*}{$\mathrm{P}_{\mathrm{OH}}$} & $\mathrm{O}_{3}$ photolysis & 0.022 & 1.9 & 0.178 & 9.0 \\
\hline & HONO photolysis & 0.520 & 44.4 & 0.511 & 25.8 \\
\hline & OVOC photolysis & 0.007 & 0.6 & 0.018 & 0.9 \\
\hline & $\mathrm{O}_{3}+$ unsaturated VOCs & 0.009 & 0.7 & 0.010 & 0.5 \\
\hline \multirow{3}{*}{$\mathrm{P}_{\mathrm{HO}_{2}}$} & HCHO photolysis & 0.193 & 16.5 & 0.374 & 18.9 \\
\hline & OVOC photolysis & 0.210 & 17.9 & 0.434 & 21.9 \\
\hline & $\mathrm{O}_{3}+$ unsaturated VOCs & 0.004 & 0.4 & 0.005 & 0.2 \\
\hline \multirow{3}{*}{$\mathrm{P}_{\mathrm{RO}_{2}}$} & OVOCs & 0.182 & 15.5 & 0.407 & 20.5 \\
\hline & $\mathrm{VOCs}+\mathrm{NO}_{3}$ & 0.002 & 0.2 & 0.004 & 0.2 \\
\hline & $\mathrm{O}_{3}+$ unsaturated VOCs & 0.023 & 2.0 & 0.042 & 2.1 \\
\hline
\end{tabular}

${ }^{a}$ OVOC photolysis denotes the photolysis of OVOCs other than formaldehyde. ${ }^{b}$ Rate is the midday (09:00-15:00 LT) average radical production rate. ${ }^{\mathrm{c}}$ Proportion is the ratio of the target radical source to the total quantified radical primary production rates.

but may become important in circumstances of low temperature and active photochemistry. Legrand et al. (2014) reported that the interference of $\mathrm{HO}_{2} \mathrm{NO}_{2}$ in their $\mathrm{HONO}$ measurements was about $15 \%$ according to laboratory experiments. In the present study, we did not conduct in situ measurements of $\mathrm{HO}_{2} \mathrm{NO}_{2}$. To estimate the potential interference for our HONO measurements, we simulated the $\mathrm{HO}_{2} \mathrm{NO}_{2}$ concentrations at Mt. Tai in both campaigns with the MCM chemical box model constrained with all measured species, including HONO. Figure S6 shows the time series of modeled $\mathrm{HO}_{2} \mathrm{NO}_{2}$ and its comparison with the mea- sured HONO and missing HONO (measured HONO minus $[\mathrm{HONO}]_{\mathrm{pss}}$ ) concentrations. Overall, moderate concentration levels of $\mathrm{HO}_{2} \mathrm{NO}_{2}$ were predicted by the model at Mt. Tai, with average values $( \pm S D)$ of $0.07 \pm 0.06 \mathrm{ppbv}$ and $0.03 \pm 0.04 \mathrm{ppbv}$ in winter and spring, respectively. When we took a $\mathrm{HO}_{2} \mathrm{NO}_{2}$ interference of $15 \%$ (Legrand et al., $2014)$, the potential interference in the missing HONO was $16 \% \pm 15 \%$ and $11 \% \pm 10 \%$ in winter and spring, respectively. Figure S7 shows the scatterplots of missing $\mathrm{HONO}$ versus $\left[\mathrm{NO}_{2}\right] \times J\left(\mathrm{NO}_{2}\right)$, an indicator of $\mathrm{HO}_{2} \mathrm{NO}_{2}$ production. As we can see, the correlation was rather weak be- 

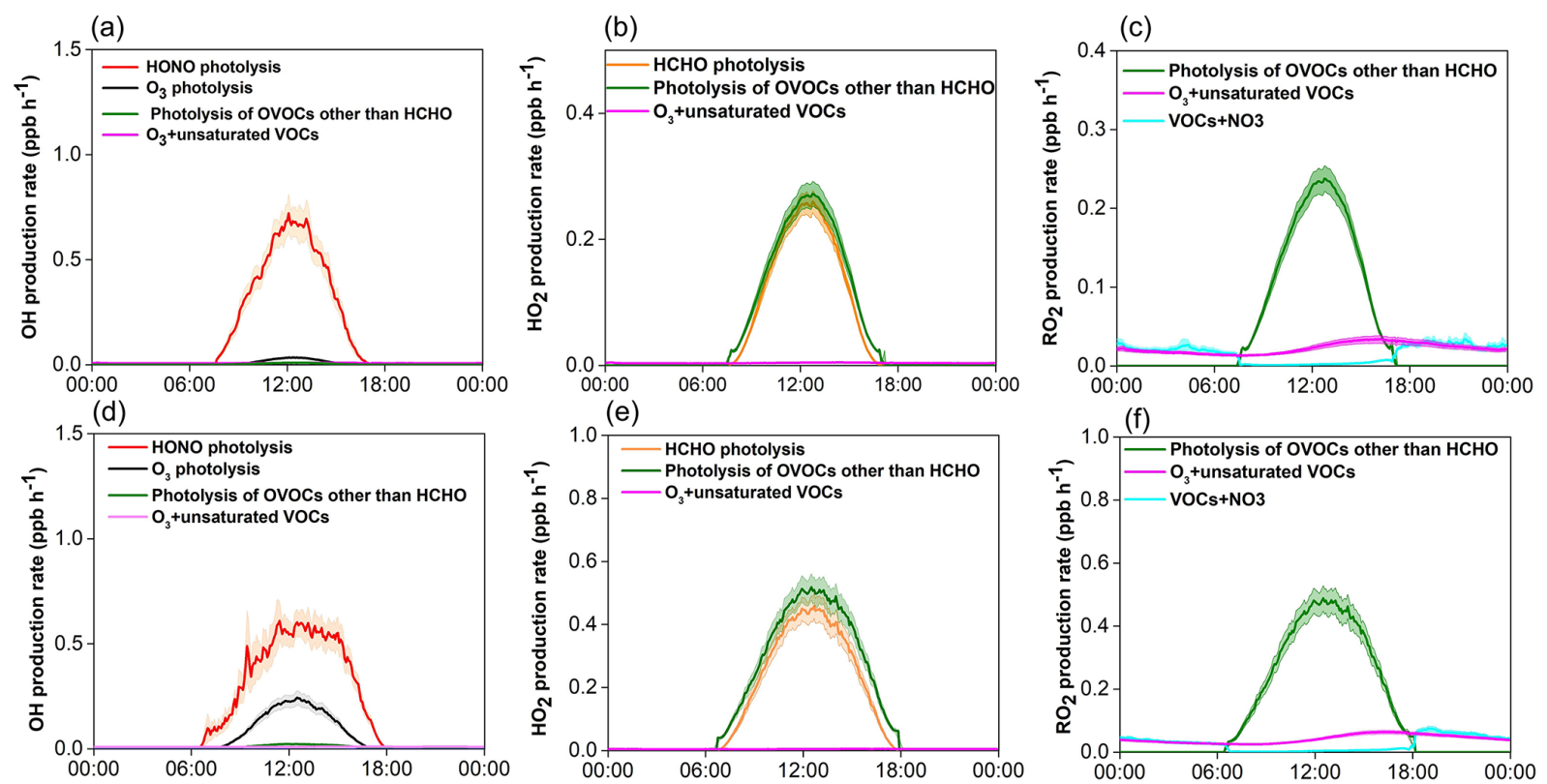

Figure 7. Model-simulated average diurnal variations of major primary sources of $\mathrm{OH}, \mathrm{HO}_{2}$, and $\mathrm{RO}_{2}$ at $\mathrm{Mt}$. Tai in winter (a, b, c) and spring $(\mathbf{d}, \mathbf{e}, \mathbf{f})$. Shaded area indicates the standard error of the data.
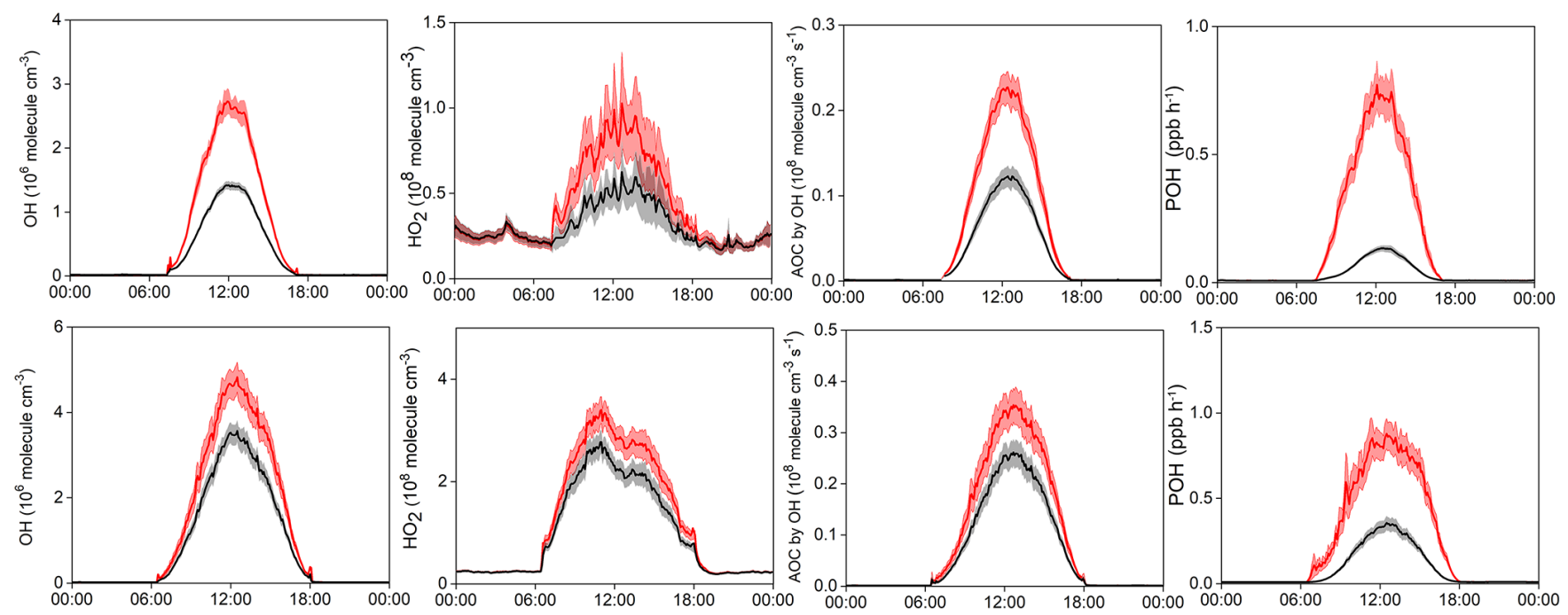

Figure 8. Model-simulated average diurnal variations of $\mathrm{OH}, \mathrm{HO}_{2}, \mathrm{AOC}$, and primary $\mathrm{OH}$ production rate $\left(\mathrm{P}_{\mathrm{OH}}\right)$ at $\mathrm{Mt}$. Tai in winter (upper panel) and spring (lower panel), with (red) and without (black) constraints of HONO measurement data. Note that the model only considers the homogenous HONO formation from $\mathrm{OH}+\mathrm{NO}$ reactions. Shaded area indicates the standard error.

tween missing $\mathrm{HONO}$ and $\left[\mathrm{NO}_{2}\right] \times J\left(\mathrm{NO}_{2}\right)$, especially in winter $(r=0.19)$. This indicates that the interference from $\mathrm{HO}_{2} \mathrm{NO}_{2}$ may not be a major factor in the determined missing $\mathrm{HONO}$, and more experiments are needed to confirm and quantify the possible interferences to the ambient $\mathrm{HONO}$ observations.

\subsection{Impacts of $\mathrm{HONO}$ on $\mathrm{OH}$ radical and atmospheric oxidation capacity}

The detailed chemical budget of $\mathrm{RO}_{x}$ radicals was explored by the observation-based MCM box model. Figure 7 shows the average diurnal profiles of primary production rates of $\mathrm{OH}, \mathrm{HO}_{2}$, and $\mathrm{RO}_{2}$ radicals from major sources at Mt. Tai during the two campaigns, and the statistical results are documented in Table 3. Two points are noteworthy here. First, the primary production rates of $\mathrm{RO}_{x}$ radicals at Mt. 
Tai were substantially lower than those derived from most of the ground-level sites over China, such as Beijing (Liu et al., 2012; Yang et al., 2018), Wuhan (Lu et al., 2017), Chengdu (Tan et al., 2018), Hong Kong (Xue et al., 2016; $\mathrm{Z}$. Li et al., 2018), and a rural site in the Yellow River Delta region (Chen et al., 2020). Note that most of these previous studies were based on modeling of the polluted photochemical episodes, but the modeled highest $\mathrm{RO}_{x}$ production rates at Mt. Tai were still lower than those in these studies. The model-simulated daily maximum AOC (defined here as the sum of reaction rates of $\mathrm{OH}$ with $\mathrm{NO}_{x}, \mathrm{SO}_{2}, \mathrm{CO}$, and VOCs) at Mt. Tai was in the range of $1.3-3.9 \times 10^{7}$ and $0.6-10.8 \times 10^{7}$ molecules $\mathrm{cm}^{-3} \mathrm{~s}^{-1}$ in winter and spring (see Fig. S8), respectively, which are still much lower than values at the abovementioned surface sites (Xue et al., 2016; Yang et al., 2018; Z. Li et al., 2018). This demonstrates the relatively lower oxidation capacity of the upper PBL and lower FT atmosphere compared to the polluted surface-layer air. Nonetheless, the primary $\mathrm{RO}_{x}$ production rates at Mt. Tai were comparable to those obtained from Hohenpeissenberg, Germany (Acker et al., 2006); Whiteface Mountain (Zhou et al., 2007); and Pinnacle State Park, a rural site in southwestern New York (Zhou et al., 2002).

Second, photolysis of HONO presents the predominant primary $\mathrm{OH}$ source, and it is also among the most important sources of $\mathrm{RO}_{x}$ at Mt. Tai. In winter, HONO photolysis was overwhelmingly the primary source of $\mathrm{RO}_{x}$ radicals, with a midday (09:00-15:00 LT) average production rate $0.520 \mathrm{ppb} \mathrm{h}^{-1}$, followed by photolysis of OVOCs other than formaldehyde $\left(0.210 \mathrm{ppb} \mathrm{h}^{-1}\right.$ for $\mathrm{HO}_{2}$ and $0.182 \mathrm{ppb} \mathrm{h}^{-1}$ for $\left.\mathrm{RO}_{2}\right)$ and formaldehyde $\left(0.193 \mathrm{ppbh}^{-1}\right.$ for $\left.\mathrm{HO}_{2}\right)$, ozonolysis reactions of unsaturated VOCs $\left(0.036 \mathrm{ppb} \mathrm{h}^{-1}\right.$ for $\left.\mathrm{RO}_{x}\right)$, and $\mathrm{O}_{3}$ photolysis $\left(0.022 \mathrm{ppbh}^{-1}\right.$ for $\left.\mathrm{OH}\right)$. In spring, in comparison, photolysis of OVOCs other than formaldehyde turns out to be the dominant $\mathrm{RO}_{x}$ source (with a midday average rate of $0.434 \mathrm{ppbh}^{-1}$ for $\mathrm{HO}_{2}$ and $0.407 \mathrm{ppb} \mathrm{h}^{-1}$ for $\mathrm{RO}_{2}$ ), followed by photolysis of HONO $\left(0.511 \mathrm{ppb} \mathrm{h}^{-1}\right.$ for $\left.\mathrm{OH}\right)$, formaldehyde $\left(0.374 \mathrm{ppbh}^{-1}\right.$ for $\left.\mathrm{HO}_{2}\right)$ and $\mathrm{O}_{3}\left(0.178 \mathrm{ppbh}^{-1}\right.$ for $\left.\mathrm{OH}\right)$, and reactions of $\mathrm{O}_{3}+$ VOCs $\left(0.057 \mathrm{ppb} \mathrm{h}^{-1}\right.$ for $\left.\mathrm{RO}_{x}\right)$. In percentage, HONO photolysis accounted for 44.4 and $25.8 \%$ of the total primary $\mathrm{RO}_{x}$ production at midday at Mt. Tai in winter and spring, respectively. For $\mathrm{OH}$ alone, the percentages of the contribution of HONO photolysis to the primary sources were 93.2 and $71.3 \%$ in winter and spring, respectively. Evidently, HONO photolysis plays a very important role in the $\mathrm{OH}$ supply and hence jump-start of atmospheric oxidation chemistry in the upper PBL and lower FT in the NCP region.

How much do the additional HONO sources (other than the homogeneous $\mathrm{OH}+\mathrm{NO}$ source) affect the atmospheric photochemistry in the upper PBL and lower FT? To evaluate this issue, two modeling scenarios were performed, with and without constraints of the measured HONO data. The model only contains the homogeneous HONO formation from $\mathrm{OH}+\mathrm{NO}$ reactions, and thus the difference be- tween both scenarios can represent the effects of the additional daytime HONO sources. Figure 8 documents the differences in the model-simulated $\mathrm{OH}, \mathrm{HO}_{2}, \mathrm{AOC}$, and $\mathrm{P}_{\mathrm{OH}}$ (primary production rate of $\mathrm{OH}$ ) between the two scenarios in winter and spring. Clearly, the model only considering the homogeneous source and without observational constraints predicted much lower levels of the $\mathrm{HO}_{x}$ radicals and AOC at Mt. Tai. Specifically, the discrepancy in the midday (09:00-15:00) average $\mathrm{P}_{\mathrm{OH}}, \mathrm{OH}, \mathrm{HO}_{2}$, and $\mathrm{AOC}$ can be up to $83.4 \%(63.7 \%), 47.2 \%(27.1 \%), 39.7 \%(20.3 \%)$, and $46.1 \%(26.4 \%)$ in winter (spring), respectively, compared to the base scenario with constraints of the measured HONO data. Given the essential role of $\mathrm{HO}_{x}$ radicals in atmospheric chemistry, the models would largely underestimate the atmospheric oxidation processes in the upper PBL and lower FT if the measurement data and/or additional HONO source mechanisms were absent. So far, direct observations of HONO in the high-elevation atmosphere are still lacking, and accurate representation of the HONO sources in atmospheric chemistry models is underway. This study highlights the significance of HONO chemistry in the upper PBL and lower FT in the NCP region, and calls for more efforts to address the tempo-spatial variations and sources of HONO in the highelevation atmosphere.

\section{Conclusions}

We analyzed the characteristics, sources, and impacts on tropospheric oxidation chemistry of ambient $\mathrm{HONO}$ in the upper PBL and lower FT of the NCP region, by conducting intensive field observations at Mt. Tai (the peak of the region) followed by detailed modeling analyses. Moderate concentration levels of HONO were observed, which are higher than those measured from other high-elevation areas around the world. HONO showed a distinctive diurnal variation pattern at Mt. Tai with a daytime concentration peak, compared to lower levels at night, which is opposite to the results determined at the ground level. The evolution of PBL and the upslope transport driven by valley breezes explained the observed daytime HONO peak. The data were compared with the year-round continuous measurement results at a nearby surface urban site to infer the vertical gradient of HONO in the NCP region. Strong additional daytime HONO sources other than homogeneous $\mathrm{OH}+\mathrm{NO}$ reactions existed in the PBL, and the PSS estimation only accounted for 18 and $12 \%$ of the observed HONO in winter and spring, respectively. The photo-enhanced heterogeneous reactions of $\mathrm{NO}_{2}$ on aerosol surface appears to be an important HONO source. HONO photolysis is the predominant primary source of $\mathrm{OH}$ radical and plays a major role in the radical chemistry at Mt. Tai. With only inclusion of the $\mathrm{OH}+\mathrm{NO}$ reactions, significant reductions of the modeled $\mathrm{OH}$ (by $\sim 47.2 \% ; 27.1 \%$ ), $\mathrm{HO}_{2}$ (by $\sim 39.7 \% ; 20.3 \%$ ), $\mathrm{P}_{\mathrm{OH}}$ (by $\sim 83.4 \% ; 63.7 \%$ ), and AOC (by $\sim 46.1 \% ; 26.4 \%$ ) were found, compared with be- 
ing constrained by observed HONO data. This study elucidates the significant role of HONO in the atmospheric oxidation chemistry in the upper PBL and lower FT of the NCP region, where previous studies mainly focused on $\mathrm{HONO}$ at the ground level.

Data availability. The measurement data and model output used in the present study can be accessed from https://data.mendeley.com/datasets/wcn84cybx9/draft?a=

e87e4e3e-4ad2-45e4-96e4-697a7533cb37 (Jiang and Xue, 2020). The code for the MCM model can be downloaded from the MCM website (http://mcm.leeds.ac.uk/MCMv3.3.1/home.htt, last access: 20 October 2020).

Supplement. The supplement related to this article is available online at: https://doi.org/10.5194/acp-20-12115-2020-supplement.

Author contributions. LX designed the research. YJ performed the field observations, analyzed data, and wrote the paper. RG, LW, PZ, TC, HL, YS, YZ, ZG, YB, and HL carried out the field observations at Mt. Tai. MJ and AD conducted the WRF-FLEXPART analyses. YZ conducted the MCM modeling analyses. LX, AD, QZ, and WW helped in the interpretation of results and revised the original manuscript.

Competing interests. The authors declare that they have no conflict of interest.

Acknowledgements. The authors thank all the staff of the Taishan National Reference Climatological Station for their logistical support and help during the field observations. We are grateful to the MCM group of the University of Leeds for provision of the MCM model. We thank the three anonymous referees, whose comments were very helpful in improving the original manuscript.

Financial support. This research has been supported by the National Key Research and Development Program of China (grant no. 2016YFC0200500), the National Natural Science Foundation of China (grant nos. 41922051 and 91544213), the Shandong Provincial Science Foundation for Distinguished Young Scholars (grant no. ZR2019JQ09), the Jiangsu Collaborative Innovation Center for Climate Change, and the Taishan Scholars (grant no. ts201712003).

Review statement. This paper was edited by James Roberts and reviewed by three anonymous referees.

\section{References}

Acker, K., Möller, D., Wieprecht, W., Auel, R., Kalaß, D., and Tscherwenka, W.: Nitrous and nitric acid measurements inside and outside of clouds at Mt. Brocken, Water Air Soil Pollut., 130, 331-336, 2001.

Acker, K., Möller, D., Wieprecht, W., Meixner, F. X., Bohn, B., Gilge, S., Plass-Dülmer, C., and Berresheim, H.: Strong daytime production of $\mathrm{OH}$ from $\mathrm{HNO}_{2}$ at a rural mountain site, Geophys. Res. Lett., 33, L02809, https://doi.org/10.1029/2005GL024643, 2006.

Alicke, B., Geyer, A., Hofzumahaus, A., Holland, F., Konrad, S., Pätz, H., Schäfer, J., Stutz, J., Volz-Thomas, A., and Platt, U.: $\mathrm{OH}$ formation by HONO photolysis during the BERLIOZ experiment, J. Geophys. Res.-Atmos., 108, PHO 3-1-PHO 3-17, 2003.

Baergen, A. M. and Donaldson, D. J.: Formation of reactive nitrogen oxides from urban grime photochemistry, Atmos. Chem. Phys., 16, 6355-6363, https://doi.org/10.5194/acp-166355-2016, 2016.

Bejan, I., Abd El Aal, Y., Barnes, I., Benter, T., Bohn, B., Wiesen, P., and Kleffmann, J. R.: The photolysis of ortho-nitrophenols: a new gas phase source of HONO, Phys. Chem. Chem. Phys., 8, 2028-2035, 2006.

Chen, T., Xue, L., Zheng, P., Zhang, Y., Liu, Y., Sun, J., Han, G., Li, H., Zhang, X., Li, Y., Li, H., Dong, C., Xu, F., Zhang, Q., and Wang, W.: Volatile organic compounds and ozone air pollution in an oil production region in northern China, Atmos. Chem. Phys., 20, 7069-7086, https://doi.org/10.5194/acp20-7069-2020, 2020.

Colussi, A. J., Enami, S., Yabushita, A., Hoffmann, M. R., Liu, W. G., Mishra, H., and Goddard, W. A.: Tropospheric Aerosol as Reactive Intermediate, Faraday Discuss., 165, 407-420, 2013.

Cui, L., Li, R., Zhang, Y., Meng, Y., Fu, H., and Chen, J.: An observational study of nitrous acid (HONO) in Shanghai, China: The aerosol impact on HONO formation during the haze episodes, Sci. Total Environ., 630, 1057-1070, 2018.

Dibb, J. E., Arsenault, M., Peterson, M. C., and Honrath, R. E.: Fast nitrogen oxide photochemistry in Summit, Greenland snow, Atmos. Environ., 36, 2501-2511, 2002.

Ding, A., Wang, T., Xue, L., Gao, J., Stohl, A., Lei, H., Jin, D., Ren, Y., Wang, X., and Wei, X.: Transport of north China air pollution by midlatitude cyclones: Case study of aircraft measurements in summer 2007, J. Geophys. Res.-Atmos., 114, D08304, https://doi.org/10.1029/2008JD011023, 2009.

Elshorbany, Y. F., Kurtenbach, R., Wiesen, P., Lissi, E., Rubio, M., Villena, G., Gramsch, E., Rickard, A. R., Pilling, M. J., and Kleffmann, J.: Oxidation capacity of the city air of Santiago, Chile, Atmos. Chem. Phys., 9, 2257-2273, https://doi.org/10.5194/acp9-2257-2009, 2009.

Elshorbany, Y. F., Steil, B., Brühl, C., and Lelieveld, J.: Impact of HONO on global atmospheric chemistry calculated with an empirical parameterization in the EMAC model, Atmos. Chem. Phys., 12, 9977-10000, https://doi.org/10.5194/acp-129977-2012, 2012.

Fu, X., Wang, T., Zhang, L., Li, Q., Wang, Z., Xia, M., Yun, H., Wang, W., Yu, C., Yue, D., Zhou, Y., Zheng, J., and Han, R.: The significant contribution of HONO to secondary pollutants during a severe winter pollution event in southern China, Atmos. Chem. Phys., 19, 1-14, https://doi.org/10.5194/acp-19-1-2019, 2019.

Gao, J., Wang, T., Ding, A., and Liu, C.: Observational study of ozone and carbon monoxide at the summit of mount Tai (1534 $\mathrm{m}$ asl) in central-eastern China, Atmos. Environ., 39, 4779-4791, 2005. 
Heland, J., Kleffmann, J., Kurtenbach, R., and Wiesen, P.: A new instrument to measure gaseous nitrous acid (HONO) in the atmosphere, Environ. Sci. Technol., 35, 3207-3212, 2001.

Hou, S., Tong, S., Ge, M., and An, J.: Comparison of atmospheric nitrous acid during severe haze and clean periods in Beijing, China, Atmos. Environ., 124, 199-206, 2016.

Jacob, D. J.: Introduction to atmospheric chemistry, Princeton University Press, 60-69, 1999.

Jenkin, M. E., Saunders, S. M., Wagner, V., and Pilling, M. J.: Protocol for the development of the Master Chemical Mechanism, MCM v3 (Part B): tropospheric degradation of aromatic volatile organic compounds, Atmos. Chem. Phys., 3, 181-193, https://doi.org/10.5194/acp-3-181-2003, 2003.

Jiang, Y. and Xue, L.: Mt.Tai HONO dataset, Mendeley Data, v1; https://doi.org/10.17632/wcn84cybx9.1, last access: 16 October 2020.

Kalthoff, N., Horlacher, V., Corsmeier, U., Volz-Thomas, A., Kolahgar, B., Geiß, H., Möllmann-Coers, M., and Knaps, A.: Influence of valley winds on transport and dispersion of airborne pollutants in the Freiburg-Schauinsland area, J. Geophys. Res.-Atmos., 105, 1585-1597, 2000.

Kleffmann, J. and Wiesen, P.: Technical Note: Quantification of interferences of wet chemical HONO LOPAP measurements under simulated polar conditions, Atmos. Chem. Phys., 8, 6813-6822, https://doi.org/10.5194/acp-8-6813-2008, 2008.

Kleffmann, J., Kurtenbach, R., Lörzer, J., Wiesen, P., Kalthoff, N., Vogel, B., and Vogel, H.: Measured and simulated vertical profiles of nitrous acid - Part I: Field measurements, Atmos. Environ., 37, 2949-2955, 2003.

Kleffmann, J., Gavriloaiei, T., Hofzumahaus, A., Holland, F., Koppmann, R., Rupp, L., Schlosser, E., Siese, M., and Wahner, A.: Daytime formation of nitrous acid: A major source of $\mathrm{OH}$ radicals in a forest, Geophys. Res. Lett., 32, L05818, https://doi.org/10.1029/2005GL022524, 2005.

Kukui, A., Legrand, M., Preunkert, S., Frey, M. M., Loisil, R., Gil Roca, J., Jourdain, B., King, M. D., France, J. L., and Ancellet, G.: Measurements of $\mathrm{OH}$ and $\mathrm{RO}_{2}$ radicals at Dome C, East Antarctica, Atmos. Chem. Phys., 14, 12373-12392, https://doi.org/10.5194/acp-14-12373-2014, 2014.

Lee, J. D., Whalley, L. K., Heard, D. E., Stone, D., Dunmore, R. E., Hamilton, J. F., Young, D. E., Allan, J. D., Laufs, S., and Kleffmann, J.: Detailed budget analysis of HONO in central London reveals a missing daytime source, Atmos. Chem. Phys., 16, 2747-2764, https://doi.org/10.5194/acp-16-2747-2016, 2016.

Legrand, M., Preunkert, S., Frey, M., Bartels-Rausch, Th., Kukui, A., King, M. D., Savarino, J., Kerbrat, M., and Jourdain, B.: Large mixing ratios of atmospheric nitrous acid (HONO) at Concordia (East Antarctic Plateau) in summer: a strong source from surface snow?, Atmos. Chem. Phys., 14, 9963-9976, https://doi.org/10.5194/acp-14-9963-2014, 2014.

Li, D., Xue, L., Wen, L., Wang, X., Chen, T., Mellouki, A., Chen, J., and Wang, W.: Characteristics and sources of nitrous acid in an urban atmosphere of northern China: results from 1-yr continuous observations, Atmos. Environ., 182, 296-306,, 2018.

Li, X., Brauers, T., Häseler, R., Bohn, B., Fuchs, H., Hofzumahaus, A., Holland, F., Lou, S., Lu, K. D., Rohrer, F., Hu, M., Zeng, L. M., Zhang, Y. H., Garland, R. M., Su, H., Nowak, A., Wiedensohler, A., Takegawa, N., Shao, M., and Wahner, A.: Exploring the atmospheric chemistry of nitrous acid (HONO) at a ru- ral site in Southern China, Atmos. Chem. Phys., 12, 1497-1513, https://doi.org/10.5194/acp-12-1497-2012, 2012.

Li, X., Holland, F., Wahner, A., Wolfe, G., Wegener, R., Hofzumahaus, A., Rohrer, F., Mentel, T. F., Brauers, T., and Bohn, B.: Missing gas-phase source of HONO inferred from Zeppelin measurements in the troposphere, Science, 348, 292-296, 2014.

Li, Z., Xue, L., Yang, X., Zha, Q., Tham, Y. J., Yan, C., Louie, P. K., Luk, C. W., Wang, T., and Wang, W.: Oxidizing capacity of the rural atmosphere in Hong Kong, Southern China, Sci. Total Environ., 612, 1114-1122, 2018.

Liu, Y., Lu, K., Li, X., Dong, H., Tan, Z., Wang, H., Zou, Q., Wu, Y., Zeng, L., and Hu, M.: A comprehensive model test of the HONO sources constrained to field measurements at rural North China Plain, Environ. Sci. Technol., 53, 3517-3525, 2019.

Liu, Z., Wang, Y., Gu, D., Zhao, C., Huey, L. G., Stickel, R., Liao, J., Shao, M., Zhu, T., Zeng, L., Amoroso, A., Costabile, F., Chang, C.-C., and Liu, S.-C.: Summertime photochemistry during CAREBeijing-2007: ROx budgets and $\mathrm{O}_{3}$ formation, Atmos. Chem. Phys., 12, 7737-7752, https://doi.org/10.5194/acp12-7737-2012, 2012

Liu, Z., Wang, Y., Costabile, F., Amoroso, A., Zhao, C., Huey, L. G., Stickel, R., Liao, J., and Zhu, T.: Evidence of aerosols as a media for rapid daytime HONO production over China, Environ. Sci. Technol., 48, 14386-14391, 2014.

Lu, X., Chen, N., Wang, Y., Cao, W., Zhu, B., Yao, T., Fung, J. C., and Lau, A. K.: Radical budget and ozone chemistry during autumn in the atmosphere of an urban site in central China, J. Geophys. Res.-Atmos., 122, 3672-3685, 2017.

Lu, X., Wang, Y., Li, J., Shen, L., and Fung, J. C.: Evidence of heterogeneous HONO formation from aerosols and the regional photochemical impact of this HONO source, Environ. Res. Lett., 13, 114002, https://doi.org/10.1088/1748-9326/aae492, 2018.

Michoud, V., Colomb, A., Borbon, A., Miet, K., Beekmann, M., Camredon, M., Aumont, B., Perrier, S., Zapf, P., Siour, G., AitHelal, W., Afif, C., Kukui, A., Furger, M., Dupont, J. C., Haeffelin, M., and Doussin, J. F.: Study of the unknown HONO daytime source at a European suburban site during the MEGAPOLI summer and winter field campaigns, Atmos. Chem. Phys., 14, 2805-2822, https://doi.org/10.5194/acp-14-2805-2014, 2014.

Monge, M. E., D’Anna, B., and Mazri, L.: Light changes the atmospheric reactivity of soot, P. Natl. Acad. Sci. USA, 107, 66056609, 2010.

Nie, W., Ding, A. J., Xie, Y. N., Xu, Z., Mao, H., Kerminen, V.-M., Zheng, L. F., Qi, X. M., Huang, X., Yang, X.Q., Sun, J. N., Herrmann, E., Petäjä, T., Kulmala, M., and Fu, C. B.: Influence of biomass burning plumes on HONO chemistry in eastern China, Atmos. Chem. Phys., 15, 1147-1159, https://doi.org/10.5194/acp-15-1147-2015, 2015.

Pan, X., Kanaya, Y., Wang, Z., Tang, X., Takigawa, M., Pakpong, P., Taketani, F., and Akimoto, H.: Using Bayesian optimization method and FLEXPART tracer model to evaluate $\mathrm{CO}$ emission in East China in springtime, Environ. Sci. Pollut. R., 21, 3873 3879, 2014.

Platt, U., Perner, D., Harris, G., Winer, A., and Pitts, J. j.: Observations of nitrous acid in an urban atmosphere by differential optical absorption, Nature, 285, 312-314, 1980.

Qin, M., Xie, P., Su, H., Gu, J., Peng, F., Li, S., Zeng, L., Liu, J., Liu, W., and Zhang, Y.: An observational study of the HONO- 
$\mathrm{NO}_{2}$ coupling at an urban site in Guangzhou City, South China, Atmos. Environ., 43, 5731-5742, 2009.

Saunders, S. M., Jenkin, M. E., Derwent, R. G., and Pilling, M. J.: Protocol for the development of the Master Chemical Mechanism, MCM v3 (Part A): tropospheric degradation of nonaromatic volatile organic compounds, Atmos. Chem. Phys., 3, 161-180, https://doi.org/10.5194/acp-3-161-2003, 2003.

Simpson, I. J., Blake, N. J., Barletta, B., Diskin, G. S., Fuelberg, H. E., Gorham, K., Huey, L. G., Meinardi, S., Rowland, F. S., Vay, S. A., Weinheimer, A. J., Yang, M., and Blake, D. R.: Characterization of trace gases measured over Alberta oil sands mining operations: 76 speciated $\mathrm{C}_{2}-\mathrm{C}_{10}$ volatile organic compounds (VOCs), $\mathrm{CO}_{2}, \mathrm{CH}_{4}, \mathrm{CO}, \mathrm{NO}, \mathrm{NO}_{2}, \mathrm{NOy}, \mathrm{O}_{3}$ and $\mathrm{SO}_{2}$, Atmos. Chem. Phys., 10, 11931-11954, https://doi.org/10.5194/acp-1011931-2010, 2010.

Sleiman, M., Gundel, L. A., Pankow, J. F., Jacob, P., and Destaillats, H.: Formation of carcinogens indoors by surface-mediated reactions of nicotine with nitrous acid, leading to potential thirdhand smoke hazards, P. Natl. Acad. Sci. USA, 107, 6576-6581, 2010.

Sörgel, M., Trebs, I., Wu, D., and Held, A.: A comparison of measured HONO uptake and release with calculated source strengths in a heterogeneous forest environment, Atmos. Chem. Phys., 15, 9237-9251, https://doi.org/10.5194/acp-15-9237-2015, 2015.

Stohl, A., Forster, C., Eckhardt, S., Spichtinger, N., Huntrieser, H., Heland, J., Schlager, H., Wilhelm, S., Arnold, F., and Cooper, O.: A backward modeling study of intercontinental pollution transport using aircraft measurements, J. Geophys. Res.-Atmos., 108, 4370, https://doi.org/10.1029/2002JD002862, 2003.

Su, H., Cheng, Y. F., Cheng, P., Zhang, Y. H., Dong, S., Zeng, L. M., Wang, X., Slanina, J., Shao, M., and Wiedensohler, A.: Observation of nighttime nitrous acid (HONO) formation at a nonurban site during PRIDE-PRD2004 in China, Atmos. Environ., 42, 6219-6232, 2008a.

Su, H., Cheng, Y. F., Shao, M., Gao, D. F., Yu, Z. Y., Zeng, L. M., Slanina, J., Zhang, Y. H., and Wiedensohler, A.: Nitrous acid (HONO) and its daytime sources at a rural site during the 2004 PRIDE-PRD experiment in China, J. Geophys. Res.-Atmos., 113, D14312, https://doi.org/10.1029/2007JD009060, 2008 b.

Su, H., Cheng, Y., Oswald, R., Behrendt, T., Trebs, I., Meixner, F. X., Andreae, M. O., Cheng, P., Zhang, Y., and Poschl, U.: Soil nitrite as a source of atmospheric $\mathrm{HONO}$ and $\mathrm{OH}$ radicals, Science, 333, 1616-1618, 2011.

Sun, L., Xue, L., Wang, T., Gao, J., Ding, A., Cooper, O. R., Lin, M., Xu, P., Wang, Z., Wang, X., Wen, L., Zhu, Y., Chen, T., Yang, L., Wang, Y., Chen, J., and Wang, W.: Significant increase of summertime ozone at Mount Tai in Central Eastern China, Atmos. Chem. Phys., 16, 10637-10650, https://doi.org/10.5194/acp-1610637-2016, 2016.

Tan, Z., Lu, K., Jiang, M., Su, R., Dong, H., Zeng, L., Xie, S., Tan, Q., and Zhang, Y.: Exploring ozone pollution in Chengdu, southwestern China: a case study from radical chemistry to $\mathrm{O}_{3}$-VOC$\mathrm{NO}_{x}$ sensitivity, Sci. Total Environ., 636, 775-786, 2018.

Tong, S., Hou, S., Zhang, Y., Chu, B., Liu, Y., He, H., Zhao, P., and Ge, M.: Exploring the nitrous acid (HONO) formation mechanism in winter Beijing: direct emissions and heterogeneous production in urban and suburban areas, Faraday Discuss., 189, 213230, 2016.

VandenBoer, T. C., Brown, S. S., Murphy, J. G., Keene, W. C., Young, C. J., Pszenny, A., Kim, S., Warneke, C., de Gouw, J.
A., Maben, J. R, Wagner, N. L., Riedel T. P., Thornton, J. A., Wolfe, D. E., Dubé, W. P., Öztürk, F., Brock, C. A., Grossberg, N., Lefer, B., Lerner, B., Middlebrook, A. M., and Roberts, J. M.: Understanding the role of the ground surface in HONO vertical structure: high resolution vertical profiles during NACHTT-11, J. Geophys. Res.-Atmos., 118, 10155-10171, 2013.

Villena, G., Kleffmann, J., Kurtenbach, R., Wiesen, P., Lissi, E., Rubio, M. A., Croxatto, G., and Rappenglück, B.: Vertical gradients of $\mathrm{HONO}, \mathrm{NO}_{x}$ and $\mathrm{O}_{3}$ in Santiago de Chile, Atmos. Environ., 45, 3867-3873, 2011.

Wang, J., Zhang, X., Guo, J., Wang, Z., and Zhang, M.: Observation of nitrous acid (HONO) in Beijing, China: seasonal variation, nocturnal formation and daytime budget, Sci. Total Environ., 587, 350-359, 2017.

Wang, X., Wang, C., and Li, Q.: Wind regimes above and below a temperate deciduous forest canopy in complex terrain: interactions between slope and valley winds, Atmosphere, 6, 60-87, 2015.

Wen, L., Xue, L., Wang, X., Xu, C., Chen, T., Yang, L., Wang, T., Zhang, Q., and Wang, W.: Summertime fine particulate nitrate pollution in the North China Plain: increasing trends, formation mechanisms and implications for control policy, Atmos. Chem. Phys., 18, 11261-11275, https://doi.org/10.5194/acp-18-112612018, 2018.

Wen, L., Chen, T., Zheng, P., Wu, L., Wang, X., Mellouki, A., Xue, L., and Wang, W.: Nitrous acid in marine boundary layer over eastern Bohai Sea, China: characteristics, sources, and implications, Sci. Total Environ., 670, 282-291, 2019.

Wong, K. W., Tsai, C., Lefer, B., Haman, C., Grossberg, N., Brune, W. H., Ren, X., Luke, W., and Stutz, J.: Daytime HONO vertical gradients during SHARP 2009 in Houston, TX, Atmos. Chem. Phys., 12, 635-652, https://doi.org/10.5194/acp-12-6352012, 2012.

Xu, Z., Wang, T., Wu, J., Xue, L., Chan, J., Zha, Q., Zhou, S., Louie, P. K., and Luk, C. W.: Nitrous acid (HONO) in a polluted subtropical atmosphere: seasonal variability, direct vehicle emissions and heterogeneous production at ground surface, Atmos. Environ., 106, 100-109, 2015.

Xue, L. K., Wang, T., Gao, J., Ding, A. J., Zhou, X. H., Blake, D. R., Wang, X. F., Saunders, S. M., Fan, S. J., Zuo, H. C., Zhang, Q. Z., and Wang, W. X.: Ground-level ozone in four Chinese cities: precursors, regional transport and heterogeneous processes, Atmos. Chem. Phys., 14, 13175-13188, https://doi.org/10.5194/acp-1413175-2014, 2014.

Xue, L., Gu, R., Wang, T., Wang, X., Saunders, S., Blake, D., Louie, P. K. K., Luk, C. W. Y., Simpson, I., Xu, Z., Wang, Z., Gao, Y., Lee, S., Mellouki, A., and Wang, W.: Oxidative capacity and radical chemistry in the polluted atmosphere of Hong Kong and Pearl River Delta region: analysis of a severe photochemical smog episode, Atmos. Chem. Phys., 16, 9891-9903, https://doi.org/10.5194/acp-16-9891-2016, 2016.

Yang, X., Xue, L., Wang, T., Wang, X., Gao, J., Lee, S., Blake, D. R., Chai, F., and Wang, W.: Observations and explicit modeling of summertime carbonyl formation in Beijing: identification of key precursor species and their impact on atmospheric oxidation chemistry, J. Geophys. Res.-Atmos., 123, 1426-1440, 2018.

Ye, C., Zhou, X., Pu, D., Stutz, J., Festa, J., Spolaor, M., Tsai, C., Cantrell, C., Mauldin, R. L., and Campos, T.: Rapid cycling of 
reactive nitrogen in the marine boundary layer, Nature, 532, 489491,2016

Ye, C., Zhou, X., Pu, D., Stutz, J., Festa, J., Spolaor, M., Tsai, C., Cantrell, C., Mauldin III, R. L., Weinheimer, A., Hornbrook, R. S., Apel, E. C., Guenther, A., Kaser, L., Yuan, B., Karl, T., Haggerty, J., Hall, S., Ullmann, K., Smith, J., and Ortega, J.: Tropospheric HONO distribution and chemistry in the southeastern US, Atmos. Chem. Phys., 18, 9107-9120, https://doi.org/10.5194/acp-18-9107-2018, 2018.

Yu, Y., Galle, B., Panday, A., Hodson, E., Prinn, R., and Wang, S.: Observations of high rates of $\mathrm{NO}_{2}-\mathrm{HONO}$ conversion in the nocturnal atmospheric boundary layer in Kathmandu, Nepal, Atmos. Chem. Phys., 9, 6401-6415, https://doi.org/10.5194/acp-9-64012009, 2009.

Zhang, N., Zhou, X., Shepson, P. B., Gao, H., Alaghmand, M., and Stirm, B.: Aircraft measurement of HONO vertical profiles over a forested region, Geophys. Res. Lett., 36, 172-173, 2009.

Zhou, X., Civerolo, K., Dai, H., Gu, H., Schwab, J., and Demerjian, K.: Summertime nitrous acid chemistry in the atmospheric boundary layer at a rural site in New York State, J. Geophys. Res.-Atmos., 107, ACH-13-1-ACH 13-11, 2002.
Zhou, X., Gao, H., He, Y., Huang, G., Bertman, S. B., Civerolo, K., and Schwab, J.: Nitric acid photolysis on surfaces in low- $\mathrm{NO}_{x}$ environments: significant atmospheric implications, Geophys. Res. Lett., 30, 2217, https://doi.org/10.1029/2003GL018620, 2003.

Zhou, X., Gu, H., Civerolo, K., Roychowdhury, U., and Demerjian, K. L.: Summertime observations of $\mathrm{HONO}, \mathrm{HCHO}$, and $\mathrm{O}_{3}$ at the summit of Whiteface Mountain, New York, J. Geophys. Res.Atmos., 112, D08311, https://doi.org/10.1029/2006JD007256, 2007.

Zhou, Y., Wang, T., Gao, X., Xue, L., Wang, X., Wang, Z., Gao, J., Zhang, Q., and Wang, W.: Continuous observations of watersoluble ions in $\mathrm{PM}_{2.5}$ at Mount Tai $(1534 \mathrm{masl})$ in centraleastern China, J. Atmos. Chem., 64, 107-127, 2010.

Ziemba, L. D., Dibb, J. E., Griffin, R. J., Anderson, C. H., Whitlow, S. I., Lefer, B. L., Rappenglück, B., and Flynn, J.: Heterogeneous conversion of nitric acid to nitrous acid on the surface of primary organic aerosol in an urban atmosphere, Atmos. Environ., 44, 4081-4089, 2010 